\title{
Analysis of Protein Covalent Modification by Xenobiotics using a Covert Oxidatively Activated Tag:
}

\author{
Raloxifene Proof-of-Principle Study \\ Ju Liu, Qian Li, Xiaofeng Yang, Richard B. van Breemen, Judy L. Bolton, and Gregory R. J. \\ Thatcher \\ Medicinal Chemistry and Pharmacognosy, College of Pharmacy, University of Illinois at Chicago, \\ 833 South Wood Street, M/C 781, Chicago, IL 60612
}

\section{Abstract}

Numerous xenobiotics, including therapeutics agents, are substrates for bioactivation to electrophilic reactive intermediates that may covalently modify biomolecules. Selective estrogen receptor modulators (SERMs) are in clinical use for long-term therapy of postmenopausal syndromes and chemoprevention, and provide a potential alternative for hormone replacement therapy (HRT). Raloxifene, in common with many SERMs and other xenobiotics, is a polyaromatic phenol that has been shown to be metabolically bioactivated to electrophilic and redox active quinoids. Nucleic acid and glutathione adduct formation has been reported, but little is known about protein covalent modification. A novel COATag (covert oxidatively activated tag) was synthesized in which raloxifene was linked to biotin. The COATag was reactive towards a model protein, human glutathione-S-transferase P1-1, in the presence but not absence of monooxygenase. The covalent modification of proteins in rat liver microsomal incubations was NADPH-dependent implicating cytochrome P450 oxidase. The COATag facilitated isolation and identification of covalently modified microsomal proteins: cytosolic glucose regulated protein (GRP78/BiP); three protein disulfide isomerases; and microsomal glutathione S-transferase 1. Oxidative metabolism of raloxifene produces reactive intermediates of sufficient lifetime to covalently modify proteins in tissue microsomes, behaviour anticipated for other polyaromatic phenol xenobiotics that can be tested by the COATag methodology. The combined use of a COATag with a simple biotin-linked electrophile (such as an iodoacetamide tag) is a new technique that allows quantification of protein covalent modification via alkylation versus oxidation in response to xenobiotic reactive intermediates. The identification of modified proteins is important for defining pathways that might lead alternatively to either cytotoxicity or to cytoprotection.

\section{INTRODUCTION}

\begin{abstract}
Hormone replacement therapy (HRT) represents a centerpiece in contemporary women's healthcare, but recent revelations from the Women's Health Initiative have seriously questioned the benefits of HRT when compared to elevated risks demonstrated in these clinical trials, including increased breast cancer and stroke (1). Postmenopausal therapeutic targets for HRT include osteoporosis, for which the selective estrogen receptor modulator (SERM), raloxifene, provides a clinical alternative (2). Moreover, raloxifene is currently in clinical trials for the prevention of breast cancer in high risk women (STAR trial; studies on tamoxifen and raloxifene) and for reduction of cardiovascular disease risk factors (RUTH trial). SERMs represent promising potential clinical substitutes for current HRT agents.
\end{abstract}


The prototype SERM, tamoxifen, is an estrogen antagonist in breast tissue, has been used clinically in all stages of breast cancer, and is being used as a chemopreventive agent in women at risk of developing breast cancer; (3) however, prolonged use of tamoxifen has been associated with development of uterine cancer and an increase in the incidence of endometrial cancer $(4,5)$. The active, oxidative metabolite, 4-hydroxytamoxifen, is a polyaromatic phenol that can be oxidized further to quinoid reactive intermediates that have been observed to form glutathione (GSH) conjugates and nucleic acid adducts (6). The detection of DNA adducts in women on tamoxifen therapy supports a genotoxic pathway resulting from oxidative bioactivation of tamoxifen (7).

In addition to tamoxifen and raloxifene, later generation SERMs including arzoxifene and acolbifene are currently in clinical studies or usage for postmenopausal syndromes including osteoporosis and dyslipidemia. These SERMs, in common with equilenin, an equine estrogen component of the HRT agent Premarin ${ }^{\circledR}$, are polyaromatic phenols that are expected to undergo oxidative bioactivation to generate redox active and electrophilic quinoid metabolites (Scheme 1) (8). Formation of adducts with GSH and nucleic acids has been confirmed in vitro for the major phase I metabolite of equilenin, 4-hydroxyequilenin, as well as for 4hydroxytamoxifen, raloxifene, acolbifene, and arzoxifene (8-13). Identification of adduct formation with proteins is less straightforward. Protein covalent modification by raloxifene was not confirmed for P450 3A4, despite raloxifene being a substrate and an irreversible inhibitor of this isozyme (13). Indeed, a recent study claimed the first direct mass spectrometric evidence for the covalent modification of cytochrome P450 3A4 by xenobiotics, using two model compounds (14).

Many other xenobiotics are bioactivated to electrophilic reactive intermediates which may covalently modify biomolecules, including those that form quinoids, such as acetaminophen and diclofenac (15). Demonstration of covalent modification of cellular proteins usually relies on use of radioligands, which has many limitations. We have sought to establish a general approach for the quantitative analysis and identification of modification due to formation of oxidative metabolites of xenobiotics employing immunolabeling and LC-MS-MS (Scheme 2). This simple approach uses a "covert oxidatively activated tag" (COATag) that requires synthesis of a molecule containing the xenobiotic and a biotin-linker moiety (Scheme 3). The hypothesis is that the COATag will not be inherently reactive towards cellular proteins; however, in the presence of cellular or exogenous oxidants, the COATag will covalently modify proteins. The utility is that the COATagged proteins can be identified by immunofocusing, immunoblotting, and mass spectroscopic analysis.

The COATag represents a covert or masked quinoid electrophile. Conversely, a bare electrophilic reagent, such as iodoacetamide attached to a biotin-linker (IAtag), will react with cellular protein thiols without need for bioactivation, and further, will show decreased reactivity in the presence of oxidants because of protein thiol oxidation (16) (Scheme 4). The combined application of a COATag with the IAtag allows assessment of protein modification by both covalent adduction and protein oxidation. Thus for the example depicted in Scheme 4, using alternately, (1) the quantitation of tagged proteins in incubations with SERM-

COATag; and (2) the quantitation of tagged proteins in incubations with SERM and Itag, allows assay of protein adduction and protein oxidation+adduction, respectively.

Covalent modification of proteins is usually seen as an undesirable property of xenobiotics, with potential consequences such as altered enzyme activity, gene transcription, cell signaling, protein turnover, or disruption of cytoskeletal integrity (17). For several xenobiotics, protein modification and enzyme inactivation might be the primary mechanism of toxicity (18). However, protein modification not only elicits cytotoxic/genotoxic pathways, but can also induce chemopreventive mechanisms (19). Since SERMs are intended for long-term therapy 
in healthy but at risk women, there is a need to identify and examine protein covalent modification and to understand the influence of SERM structure on modification and the identity of protein targets. Herein, the application of a novel COATag is reported in combination with an IAtag in the study of modification of both isolated model proteins and proteins in liver microsomes. A raloxifene COATag was selected for this proof-of-principle study, providing for the first time identification of a number of proteins that are covalently modified by the oxidative metabolites of a SERM, formed in situ in a tissue microsomal system.

\section{EXPERIMENTAL}

\section{Materials}

All solvents and chemicals were purchesed from Aldrich Chemical (Milwaukee, WI), Fisher Scientific (Itasca, IL), or Sigma (St. Louis, MO) unless stated otherwise. Trypsin (sequencing grade) was purchesed from Promega (Madison, WI), and NAPTM 5 columns and ECL from Amersham Biosciences (Piscataway, NJ). LC-Biotin, IAtag and UltraLink® Immobilized Monomeric Avidin were obtained from Pierce (Rockford, IL). NuPAGE® precast gels and XCell SureLock ${ }^{\mathrm{TM}}$ Mini-Cell were purchesed from Invitrogen (Carlsbad, CA). hGST P1-1 (EC 2.5.1.18) was prepared as described previously (20). GRP78/Bip and mGST1 antibodies were the generous gifts of Dr. Sylvie Y. Blond (University of Illinois at Chicago, IL) (21) and Dr. Brian M. Bennett (Queen's University, Kingston, ON, Canada) (22), respectively. 4-OHEN was synthesized by treating equilin with Fremy's salt as described previously (9).

Densitometric quantitation of western blot images was carried out using Scion Image (Scion, Frederick, MD). All western blots shown are representative of triplicate analyses ( $2 \mu \mathrm{g}$ proteins/ lane).

\section{Synthesis}

The raloxifene COATag synthesis is described below (Scheme 3). In this paper, the "the COATag" refers to the raloxifene COATag, since this is the only example of a COATag studied in this work. The COATag was characterized and assayed for purity in subsequent batches by HPLC using UV and MS detection (see Supporting Information).

\section{Synthesis of Raloxifene COATag - 6-methoxy-2-(p-methoxyphenyl)benzo[b] thien-3-yl p-methoxyphenyl ketone (I)—Compounds I and II were synthesized by} adaptation of literature procedures (Scheme 3). Briefly, $p$-anisoyl chloride (1.54 g, $9.00 \mathrm{mmol}$ ) was added to a cold solution of 6-methoxyphenyl-2-(4-methoxyphenyl)-benzo[b]thiophene $(1.62 \mathrm{~g}, 6.00 \mathrm{mmol})$ in anhydrous $\mathrm{CH}_{2} \mathrm{Cl}_{2}(100 \mathrm{~mL})$. To this mixture, $\mathrm{AlCl}_{3}(1.20 \mathrm{~g}, 9.00 \mathrm{mmol})$ was added and stirred for $1 \mathrm{~h}$. The reaction mixture was poured into ice-water $(150 \mathrm{~mL})$ and extracted with $\mathrm{CH}_{2} \mathrm{Cl}_{2}$. The organic layer was washed with $1 \mathrm{M} \mathrm{NaOH}$ and brine and dried over $\mathrm{Na}_{2} \mathrm{SO}_{4}$. After removal of the solvent, the crude product was purified by flash chromatography on a silica column first by ethyl acetate/hexanes $(3: 7, v / v)$, and then by methylene chloride/ethyl acetate (19:1, v/v) to yield $2.0 \mathrm{~g}(83 \%)$ of compound I. ${ }^{1} \mathrm{H}$ NMR (300 $\mathrm{MHz}$, acetone- $\left.d_{-6}\right): \delta 3.74(\mathrm{~s}, 3 \mathrm{H}), 3.80(\mathrm{~s}, 3 \mathrm{H}), 3.89(\mathrm{~s}, 3 \mathrm{H}), 6.85\left(\mathrm{~d}, J=8.7 \mathrm{H}_{\mathrm{Z}}, 2 \mathrm{H}\right), 6.88(\mathrm{~d}$, $\left.J=8.7 \mathrm{H}_{\mathrm{Z}}, 2 \mathrm{H}\right), 7.00\left(\mathrm{dd}, J=8.9,2.3 \mathrm{H}_{\mathrm{Z}}, 1 \mathrm{H}\right), 7.36\left(\mathrm{~d}, J=8.8 \mathrm{H}_{\mathrm{Z}}, 2 \mathrm{H}\right), 7.45\left(\mathrm{~d}, J=8.9 \mathrm{H}_{\mathrm{Z}}\right.$, $1 \mathrm{H}), 7.55\left(\mathrm{~d}, J=2.3 \mathrm{H}_{\mathrm{Z}}, 1 \mathrm{H}\right), 7.73\left(\mathrm{~d}, J=8.9 \mathrm{H}_{\mathrm{Z}}, 2 \mathrm{H}\right)$. Electrospray MS $[\mathrm{M}+\mathrm{H}]^{+} \mathrm{m} / z .405 .4$ $(100 \%)$.

\section{(4-hydroxyphenyl)[6-methoxy-2-(4-methoxyphenyl)benzo[b]thien-3-y]}

methanone (II)-A solution of compound I $(0.4 \mathrm{~g}, 1 \mathrm{mmol})$ in dry DMF $(2 \mathrm{~mL})$ was added to a solution of sodium ethanethioate $(1.5 \mathrm{mmol}$ in $3 \mathrm{~mL} \mathrm{DMF})$. The reaction mixture was heated at $80^{\circ} \mathrm{C}$ for $4 \mathrm{~h}$ and then cooled to room temperature. Ethyl acetate $(10 \mathrm{~mL})$ and water $(10 \mathrm{~mL})$ were added to the mixture. After neutralization with $1 \mathrm{M} \mathrm{HCl}$, the reaction mixture was extracted with ethyl acetate $(3 \times 30 \mathrm{~mL})$. The organic layer was removed, washed with 
brine, and dried over $\mathrm{Na}_{2} \mathrm{SO}_{4}$. After removal of the solvent, the crude product was purified by flash chromatography on a silica column with ethyl acetate/hexanes $(3: 7, \mathrm{v} / \mathrm{v})$ to yield $0.35 \mathrm{~g}$ (89\%) of compound II. ${ }^{1} \mathrm{H}$ NMR $(300 \mathrm{MHz}$, acetone- $d-6)$ ) $\delta 3.76(\mathrm{~s}, 3 \mathrm{H}), 3.88(\mathrm{~s}, 3 \mathrm{H}), 6.89(\mathrm{~d}$, $\left.J=8.8, \mathrm{H}_{\mathrm{Z}}, 2 \mathrm{H}\right), 6.91\left(\mathrm{~d}, J=8.6 \mathrm{H}_{\mathrm{Z}}, 2 \mathrm{H}\right), 7.00\left(\mathrm{dd}, J=8.9,2.3 \mathrm{H}_{\mathrm{Z}}, 1 \mathrm{H}\right), 7.38\left(\mathrm{~d}, J=8.8 \mathrm{H}_{\mathrm{Z}}\right.$, $2 \mathrm{H}), 7.44\left(\mathrm{~d}, J=8.9 \mathrm{H}_{\mathrm{Z}}, 1 \mathrm{H}\right), 7.56\left(\mathrm{~d}, J=2.3 \mathrm{H}_{\mathrm{Z}}, 1 \mathrm{H}\right), 7.74\left(\mathrm{~d}, J=8.8 \mathrm{H}_{\mathrm{Z}}, 2 \mathrm{H}\right)$. Electrospray MS $[\mathrm{M}+\mathrm{H}]^{+} \mathrm{m} / z 391.1(100 \%)$.

\section{6-methoxy-2-(4-methoxyphenyl)benzo[b]thien-3-yl 4-[2-(1-N-boc)ethoxy]} phenyl]methanone (III)-To a solution of compound II $(0.390 \mathrm{~g}, 1 \mathrm{mmol})$ in anhydrous methyl ethyl ketone $(2.5 \mathrm{~mL})$ was added $\mathrm{K}_{2} \mathrm{CO}_{3}(0.207 \mathrm{~g}, 1.5 \mathrm{mmol})$ followed by 2-bromo-N(boc)ethylamine $(0.224 \mathrm{~g}, 1 \mathrm{mmol})$. The solution was refluxed for $24 \mathrm{~h}$. The mixture was then cooled to room temperature, filtered, and concentrated. Purification of the crude residue by flash chromatography on silica gel using chloroform/ethyl acetate as mobile phase $(1: 3, \mathrm{v} / \mathrm{v})$ gave compound III as a yellow solid $0.37 \mathrm{~g}(69 \%) .{ }^{1} \mathrm{HNMR}\left(300 \mathrm{MHz}\right.$, acetone- $\left.d_{-6}\right): \delta 1.39$ (s, 9H), $3.44\left(\mathrm{dd}, J=11.4,5.6 \mathrm{H}_{\mathrm{Z}}, 2 \mathrm{H}\right), 3.74(\mathrm{~s}, 3 \mathrm{H}), 3.87(\mathrm{~s}, 3 \mathrm{H}), 4.07\left(\mathrm{t}, J=5.6 \mathrm{H}_{\mathrm{Z}}, 2 \mathrm{H}\right)$, $6.20(\mathrm{bs}, 1 \mathrm{H}), 6.86\left(\mathrm{~d}, J=8.8 \mathrm{H}_{\mathrm{Z}}, 2 \mathrm{H}\right), 6.90\left(\mathrm{~d}, J=8.9 \mathrm{H}_{\mathrm{Z}}, 2 \mathrm{H}\right), 7.00\left(\mathrm{dd}, J=8.9,2.4 \mathrm{H}_{\mathrm{Z}}, 1 \mathrm{H}\right)$, $7.38\left(\mathrm{~d}, J=8.8 \mathrm{H}_{\mathrm{Z}}, 2 \mathrm{H}\right), 7.45\left(\mathrm{~d}, J=8.8 \mathrm{H}_{\mathrm{Z}}, 1 \mathrm{H}\right), 7.56\left(\mathrm{~d}, J=2.4 \mathrm{H}_{\mathrm{Z}}, 1 \mathrm{H}\right), 7.74(\mathrm{~d}, J=8.9$ $\left.\mathrm{H}_{\mathrm{Z}}, 2 \mathrm{H}\right)$. Electrospray MS $[\mathrm{M}+\mathrm{H}]^{+} \mathrm{m} / 2.534 .2(100 \%)$.

\section{6-hydroxy-2-(4-hydroxyphenyl)benzo[b]thien-3-yl 4-[2-(1-amino)ethoxy]phenyl] methanone (IV)-A solution of compound III ( $1 \mathrm{~g}, 1.88 \mathrm{mmol})$ in dry $\mathrm{CH}_{2} \mathrm{Cl}_{2}(15 \mathrm{~mL})$ under} Ar was cooled in an ice-isopropanol bath and then $\mathrm{BBr}_{3}(1 \mathrm{M}$ in ether, $15 \mathrm{~mL})$ was added. After removal from the ice bath, the mixture was stirred vigorously for $3 \mathrm{~h}$ at room temperature and then quenched with ice water $(5 \mathrm{~mL})$. The residue was dissolved by adding $5 \%$ methanol in ethyl acetate $(50 \mathrm{~mL})$. The organic layer was washed with saturated $\mathrm{NaHCO}_{3}(2 \times 50 \mathrm{~mL})$, and brine $(2 \times 50 \mathrm{~mL})$, dried over $\mathrm{Na}_{2} \mathrm{SO}_{4}$, and concentrated. The crude product was further purified by flash chromatography on $\mathrm{SiO} 2$ using methylene chloride/methanol/ammonia (aq.) $(8: 1: 0.1, \mathrm{v} / \mathrm{v} / \mathrm{v})$ as mobile phase to give IV $(0.6 \mathrm{~g})$ as a yellow solid $(79 \%) .{ }^{1} \mathrm{H}$ NMR $(300 \mathrm{MHz}$, acetone- $\left.d_{-6}\right): \delta 1.85(\mathrm{~b}, 1 \mathrm{H}), 1.88(\mathrm{~b}, 1 \mathrm{H}), 3.57\left(\mathrm{t}, J=5.7 \mathrm{H}_{\mathrm{Z}}, 2 \mathrm{H}\right), 4.21\left(\mathrm{t}, J=5.8 \mathrm{H}_{\mathrm{Z}}, 2 \mathrm{H}\right)$, $6.73\left(\mathrm{~d}, J=8.6 \mathrm{H}_{\mathrm{Z}}, 2 \mathrm{H}\right), 6.85\left(\mathrm{~d}, J=8.8 \mathrm{H}_{\mathrm{Z}}, 2 \mathrm{H}\right), 6.94\left(\mathrm{dd}, J=8.7,2.2 \mathrm{H}_{\mathrm{Z}}, 1 \mathrm{H}\right), 7.26(\mathrm{~d}, J=$ $\left.8.6 \mathrm{H}_{\mathrm{Z}}, 2 \mathrm{H}\right), 7.38\left(\mathrm{~d}, J=8.7 \mathrm{H}_{\mathrm{Z}}, 1 \mathrm{H}\right), 7.40\left(\mathrm{~d}, J=2.2 \mathrm{H}_{\mathrm{Z}}, 1 \mathrm{H}\right), 7.71\left(\mathrm{~d}, J=8.8 \mathrm{H}_{\mathrm{Z}}, 2 \mathrm{H}\right)$. Electrospray MS $[\mathrm{M}+\mathrm{H}]^{+} \mathrm{m} / \mathrm{z} 406.2(100 \%)$.

\section{6-methoxy-2-(4-methoxyphenyl)benzo[b]thien-3-yl 4-[2-(1-biotinyl-} aminocaproyl-ethoxy]phenyl]methanone V-The mixture of compound IV (179 mg, $0.44 \mathrm{mmol})$, LC-Biotin ( $200 \mathrm{mg}, 0.44 \mathrm{mmol})$, and $\mathrm{NEt}_{3}(0.8 \mathrm{~mL}, 1.32 \mathrm{mmol})$ in dry DMF $(0.8$ $\mathrm{mL}$ ) was stirred under $\mathrm{Ar}$ for $18 \mathrm{~h}$ at room temperature. The solvent was removed and the residue was purified by chromatography on $\mathrm{SiO}_{2}$ using methylene chloride / methanol / ammonia hydroxide $(6: 1: 0.1, \mathrm{v} / \mathrm{v} / \mathrm{v})$ giving a yellow solid $200 \mathrm{mg}(61 \%) .{ }^{1} \mathrm{H}$ NMR (300 $\mathrm{MHz}$, Methanol- $d-4): \delta 0.92-1.74(\mathrm{~m}, 12 \mathrm{H}), 2.17\left(\mathrm{t}, J=7.2 \mathrm{H}_{\mathrm{Z}}, 2 \mathrm{H}\right), 2.19\left(\mathrm{t}, J=7.2 \mathrm{H}_{\mathrm{Z}}, 2 \mathrm{H}\right)$, $2.68\left(\mathrm{~d}, J=12.7 \mathrm{H}_{\mathrm{Z}}, 1 \mathrm{H}\right), 2.89\left(\mathrm{dd}, J=12.7,4.9 \mathrm{H}_{\mathrm{Z}}, 1 \mathrm{H}\right), 3.12\left(\mathrm{t}, J=6.9 \mathrm{H}_{\mathrm{Z}}, 2 \mathrm{H}\right), 3.17(\mathrm{~m}$, $1 \mathrm{H}), 3.53\left(\mathrm{t}, J=5.1 \mathrm{H}_{\mathrm{Z}}, 2 \mathrm{H}\right), 4.05\left(\mathrm{t}, J=5.2 \mathrm{H}_{\mathrm{Z}}, 2 \mathrm{H}\right), 4.27\left(\mathrm{dd}, J=7.8,4.4 \mathrm{H}_{\mathrm{Z}} 1 \mathrm{H}\right), 4.46$ (dd, $\left.J=7.8,4.9 \mathrm{H}_{\mathrm{Z}} 1 \mathrm{H}\right), 6.64\left(\mathrm{~d}, J=8.6 \mathrm{H}_{\mathrm{Z}}, 2 \mathrm{H}\right), 6.85\left(\mathrm{~d}, J=8.8 \mathrm{H}_{\mathrm{Z}}, 2 \mathrm{H}\right), 6.89(\mathrm{dd}, J=8.6,2.3$ $\left.\mathrm{H}_{\mathrm{Z}}, 1 \mathrm{H}\right), 7.19\left(\mathrm{~d}, J=8.6 \mathrm{H}_{\mathrm{Z}}, 2 \mathrm{H}\right), 7.27\left(\mathrm{~d}, J=2.1 \mathrm{H}_{\mathrm{Z}}, 1 \mathrm{H}\right), 7.41\left(\mathrm{~d}, J=8.8 \mathrm{H}_{\mathrm{Z}}, 1 \mathrm{H}\right), 7.71(\mathrm{~d}$, $\left.J=8.8 \mathrm{H}_{\mathrm{Z}}, 2 \mathrm{H}\right) .{ }^{13} \mathrm{C}$ NMR $(360 \mathrm{MHz}$, Methanol- $d-4): \delta 194.7,175.5,175.0,165.1,163.6$, $158.9,156.2,143.0,140.4,133.2,132.5,130.8,130.3,130.0,124.7,123.6,115.7,115.3,114.4$, 107.0, 66.8, 62.4, 60.6, 56.0, 40.0, 39.2, 38.9, 35.8, 29.1, 28.8, 28.5, 26.4, 25.9, 25.6. ESI - MS $\mathrm{m} / \mathrm{z}[\mathrm{M}+\mathrm{H}]^{+} 745.6(100 \%)$. The final product was assayed for purity using HPLC separation using a binary solvent system consisting of A: $0.1 \%$ formic acid in $\mathrm{H}_{2} \mathrm{O}$, and $\mathrm{B}: 0.1 \%$ formic acid in $100 \%$ acetonitrile performed on a $3.0 \mathrm{~mm} \times 150 \mathrm{~mm}$ Zorbax ${ }^{\circledR} \mathrm{SB}-\mathrm{C} 18$ column (Agilent, Palo Alto, CA ) at a flow rate of $0.4 \mathrm{~mL} / \mathrm{min}$ (Figure S1). The gradient was: 10 min linear gradient from 10- 20\% B, 30 min linear gradient from 20-40\% B, 5 min linear gradient from 
$40-95 \%$ B, isocratic $95 \%$ B for 5 min, and finally a 2 min gradient back to $10 \%$ B. Detection was by UV absorbance $(288 \mathrm{~nm})$ and by extraction LC-MS-MS ion selective monitoring $(\mathrm{m} /$ $z=745.5$ ) using an Agilent ion trap.

\section{Modification of Human Glutathione S-Transferase P1-1}

A solution containing hGST P1-1 (10 $\mu \mathrm{M})$, IAtag, or raloxifene COATag $(30 \mu \mathrm{M})$, and various adjuvants in $50 \mathrm{mM}$ phosphate buffer $(\mathrm{pH} 7.4)$ was incubated for $30 \mathrm{~min}$ at $37^{\circ} \mathrm{C}$. The reactions were terminated by chilling in an ice bath followed by the addition of $\beta$-mercaptoethanol $(0.2$ $\mathrm{mM})$. The mixture was either loaded directly onto $12 \%$ NuPAGE gel for electrophoresis, and then transblotting to the PVDF membrane for western blot analysis or passed through a NAP-5 desalting column to further remove excess IAtag for trypsin digest and mass spectrometric analysis.

\section{Mass Spectrometric Analysis of Modified Peptides from hGST P1-1}

After removing excess raloxifene COATag or IAtag, the protein mixture was diluted in ammonium bicarbonate $(50 \mathrm{mM}, 500 \mu \mathrm{L}, \mathrm{pH} 8.5)$ and digested by trypsin $(0.5 \mathrm{mg} / \mathrm{mL}, 100: 1$, $\mathrm{v} / \mathrm{v}$ ) overnight at $37^{\circ} \mathrm{C}$. The resulting peptide mixture was passed through an avidin affinity cartridge (Applied Biosystems, Foster City, CA). The cartridge was washed and eluted according to the manufacturer's instructions. The eluate was identified by using a Thermo Electron (San Jose, CA) LCQ Deca ion trap mass spectrometer equipped with a Surveyor MS pump, autosampler and a Vydac (Hesperia, CA), $5 \mu \mathrm{m}, 300 \AA \mathrm{C}_{18}$ column $(250 \times 1.0 \mathrm{~mm})$. The mobile phase consisted of the following; Solvent A: 5\% acetonitrile, $94.9 \%$ water, and $0.1 \%$ formic acid; Solvent B: $5 \%$ water, $94.9 \%$, and $0.1 \%$ formic acid. After isocratic solvent A for $5 \mathrm{~min}$, a $60 \mathrm{~min}$ linear gradient was used from 0-60\% solvent B. Peptides were identified using Web-based Mascot database (http://prospector.ucsf.edu) searching and MS/MS fitting.

\section{Modification of Proteins in Rat Liver Microsomes}

Female Sprague-Dawley rats (200-220 g) were obtained from Sasco (Omaha, NE). The rats were pretreated by intraperitoneal injections of dexamethasone, $100 \mathrm{mg} / \mathrm{kg}$ daily, for 3 consecutive days to induce the P450 3A isoenzymes, prior to sacrifice on day 4. Rat liver microsomes were prepared, and protein and P450 concentrations were determined as described previously (23). A solution containing the raloxifene COATag $(30 \mu \mathrm{M})$, rat liver microsomes ( $1 \mathrm{nmol} \mathrm{P} 450 / \mathrm{mL}, 1.5 \mathrm{mg}$ protein $/ \mathrm{mL}$ ), and a NADPH - generating system (consisting of 1.0 $\mathrm{mM} \mathrm{NADP}^{+}, 5.0 \mathrm{mM} \mathrm{MgCl} 2,5.0 \mathrm{mM}$ isocitric acid, and $0.2 \mathrm{unit} / \mathrm{mL}$ isocitrate dehydrogenase) in $50 \mathrm{mM}$ phosphate buffer ( $\mathrm{pH} 7.4$ ) was incubated for $30 \mathrm{~min}$ at $37^{\circ} \mathrm{C}$. For control incubations, either $\mathrm{NADP}^{+}$or raloxifene COATag was omitted. The reaction mixture was quenched by $\beta$ mercaptoethanol $(0.2 \mathrm{mM})$, and the mixture was either loaded directly onto NuPAGE for electrophoresis or centrifuged $(17,000 \times \mathrm{g})$ at $4{ }^{\circ} \mathrm{C}$ for $1 \mathrm{~h}$ to remove the non-soluble proteins. The supernatant was concentrated by ultrafiltration through a 5,000 MW cutoff membrane (Millipore, Bedford, MA) and then passed through a NAP-5 desalting column to remove excess raloxifene COATag prior to avidin bead affinity separation. Incubations were also carried out with NADPH in place of the enzymic NADPH generating system, with analysis carried out by western blotting as described below.

\section{Detection of Modified Proteins by NuPAGE-Western Blotting}

The modified proteins were separated using a $12 \%$ or $4-12 \%$ NuPAGE® gel with MOPS running buffer. The gels were either stained with Coomassie G250 or transferred by electroblotting onto PVDF membranes using XCell SureLock ${ }^{\mathrm{TM}}$ Mini-Cell according to the manufacturer's instructions. The membranes were blocked by $1 \%$ BSA in $0.5 \mathrm{X}$ TBST for 1 $\mathrm{h}$ at room temperature followed by washing the membranes three times at 5 min intervals. The membranes were incubated at room temperature with HRP-conjugated streptavidin (1:20,000 
dilution) and ECL for $1 \mathrm{~h}$ and $5 \mathrm{~min}$, respectively. The membranes were exposed to film for 3 $\mathrm{s}$ to $5 \mathrm{~min}$ before development.

\section{Avidin Affinity Chromatography}

Rat liver microsomes $(2.5 \mathrm{~mL}, 20 \mathrm{mg}$ protein/mL) were incubated with raloxifene COATag as described above. The separation of biotinylated proteins from the unbiotinylated proteins was performed on an Ultralink ${ }^{\circledR}$ Immobilized Monomeric Avidin column according to the manufacturer's instructions. Briefly, $15 \mathrm{~mL}$ of monovalent avidin beads (33\% slurry) were packed onto a column to yield $5 \mathrm{~mL}$ of packed gel, which was washed sequentially with $2 \times 5$ $\mathrm{mL}$ PBS (pH 7.2), $3 \times 5 \mathrm{~mL}$ biotin buffer ( $2 \mathrm{mM}$ D-biotin in PBS) to block any non-reversible biotin binding sites, $3 \times 5 \mathrm{~mL}$ glycine buffer $(0.1 \mathrm{M}$ glycine, $\mathrm{pH} 2.8)$, and finally $2 \times 10 \mathrm{~mL}$ PBS again. The protein mixture $(4 \mathrm{~mL})$ was incubated on the column containing the washed avidin beads overnight at $4{ }^{\circ} \mathrm{C}$ or for $30 \mathrm{~min}$ at room temperature, with continuous rotation (both methods giving comparable results). The beads were allowed to settle for at least $30 \mathrm{~min}$ and washed extensively with $4 \times 5 \mathrm{~mL}$ PBS to remove unbiotinylated proteins, followed by 4 $\times 5 \mathrm{~mL}$ biotin buffer to elute biotinylated proteins, and finally $4 \times 5 \mathrm{~mL}$ glycine buffer to regenerate the column. The biotinylated protein elute was concentrated to $250 \mu \mathrm{L}$ by ultrafiltration through a 5,000 molecular weight cut-off membrane and stored at $-75^{\circ} \mathrm{C}$ until analysis.

Control experiments were performed with rat liver microsomes $(2.5 \mathrm{~mL}, 20 \mathrm{mg}$ protein $/ \mathrm{mL})$ in phosphate buffer (17.5, pH 7.4) incubated without raloxifene COATag for $30 \mathrm{~min}$ at $37^{\circ} \mathrm{C}$. The mixture was centrifuged $(17,000 \times \mathrm{g})$ at $4{ }^{\circ} \mathrm{C}$ for $1 \mathrm{~h}$ to remove the non-soluble proteins. The supernatant was concentrated by ultrafiltration through a 5,000 MW cutoff membrane (Millipore, Bedford, MA). The protein mixture $(4 \mathrm{~mL}, 2 \mathrm{mg} / \mathrm{mL})$ was incubated on the pretreated avidin column $(5 \mathrm{~mL})$ for $30 \mathrm{~min}$. The column was washed extensively with $10 \times 5$ $\mathrm{mL}$ PBS to remove unbiotinylated proteins, followed by $10 \times 5 \mathrm{~mL}$ biotin buffer to elute biotinylated proteins, and finally $10 \times 5 \mathrm{~mL}$ glycine buffer to regenerate the column. The biotin eluate was concentrated by $5,000 \mathrm{MW}$ cutoff membrane to $100 \mu \mathrm{L} ; 20 \mu \mathrm{L}$ of which was used for gel electrophoresis. A second control protocol was employed in which the avidin column was washed with $10 \times 5 \mathrm{~mL}$ phosphate buffer $\left(0.1 \mathrm{M} \mathrm{K}_{2} \mathrm{PO}_{4}, 1 \mathrm{M} \mathrm{NaCl}, 0.1 \%\right.$ tween $20, \mathrm{pH}$ 5.0) to remove unbiotinylated proteins, followed by $10 \times 5 \mathrm{~mL}$ biotin buffer to elute biotinylated proteins, and finally $10 \times 5 \mathrm{~mL}$ glycine buffer to regenerate the column. In both control protocols, comparison was made with microsomes incubated with the COATag. Western blotting was used to visualize biotinylated proteins and Coommassie blue to visualize total protein.

\section{Mass Spectrometic Anaylsis of Tryptic Digests}

The concentrated biotinylated proteins ( $200 \mu \mathrm{L}$ ) from rat liver microsomes were separated by electrophoresis as described above. The gel was stained by Coomassie blue, excised, and digested with trypsin as described previously (24). Two methods were used to identify the biotinylated proteins. Method A: The protein digest from band $1(0.5 \mu \mathrm{L})$ was mixed with 0.5 $\mu \mathrm{L}$ CHCA matrix solution $(10 \mathrm{mg} / \mathrm{mL}$ of $\alpha$-cyano-4-hydroxycinnamic acid in 1:1 water/ acetonitrile containing $0.1 \%$ TFA). The mixture $(0.5 \mu \mathrm{L})$ was spotted onto the MALDI sample stage and air-dried prior to analysis. Positive ion MALDI-TOF mass spectra were acquired using an Applied Biosystems Voyager DE-Pro mass spectrometer operated in reflection mode. After time-delayed extraction, the ions were accelerated to $20 \mathrm{kV}$ for TOF mass spectrometric analysis. After peak detection, the peptide mapping data were compared to the NCBI database using MS-Fit. Method $B$ : The peptide mixture from band $2(60 \mu \mathrm{L})$ was injected onto a reversed phase column (75 $\mu \mathrm{m}$ id Zorbax Stablebond, $300 \AA$ pore) (Agilent, Palo Alto, CA) connected to an Agilent 1100 nano/capillary LC/MSD XCT system, equipped with an orthogonal nanospray interface and a nanopump. The samples were separated by HPLC using a binary 
solvent system consisting of A: $0.1 \%$ formic acid and 5\% acetonitrile in $\mathrm{H}_{2} \mathrm{O}$, and $\mathrm{B}: 0.1 \%$ formic acid in $100 \%$ acetonitrile at a flow rate of $300 \mathrm{~nL} / \mathrm{min}$. A gradient was used from $15 \%-55 \% \mathrm{~B}$ over $60 \mathrm{~min}$. The mass spectrometer was operated in positive ion mode with source conditions: Vcap - $4500 \mathrm{~V}$, drying gas flow $4 \mathrm{~L} / \mathrm{min}$, drying gas temperature $230{ }^{\circ} \mathrm{C}$ and CapEx $90 \mathrm{~V}$. Proteins were identified using Mascot database searching of parent and daughter ions and reported as a probability score (see Supporting Information for details).

\section{RESULTS}

\section{Proof-of-principle I: model protein modification by IAtag}

Recombinant human GST P1-1 was chosen as a model protein to study protein modification. The direct-acting, electrophilic IAtag is predicted to covalently modify one or more cysteine residue. hGST P1-1 contains four cysteine residues (Cys-14, Cys-47, Cys-101, and Cys-169) and is sensitive to thiol group modification, particularly at the Cys-47 and Cys-101 positions. Both of these cysteine residues were reported to be selectively labeled by the thiol-directed reagent, 7-fluoro-4-sulfamoyl-2-1,3-benzodiazole (25). Inactivation of hGST P1-1 by $N$-(4anilino-1-naphthyl) maleimide was previously reported to be accompanied by modification at Cys-47 (26): Cys-47 alkylation has been reported to prevent GSH binding at the active site (25). In our studies, hGST P1-1 was modified by IAtag selectively at Cys-47 and Cys-101 as indicated by positive ion electrospray LC-MS-MS analysis (Fig. 1). Enzyme modification is selective, not specific, because extended incubation and increased electrophile concentration lead to modification of Cys-14, Cys-47, and Cys-101 (Supporting Information).

The LC-MS-MS analysis of the tryptic digests of the IAtag modified hGST P1-1 showed two major peaks: peak 1 eluted at $18 \mathrm{~min}$ and produced a protonated molecule of $\mathrm{m} / \mathrm{z} 632.4$; and peak 2 eluted at $42 \mathrm{~min}$ and produced a doubly protonated molecule of $\mathrm{m} / \mathrm{z} 732.0$. The MSMS product ion scan of the protonated molecule of $\mathrm{m} / z 632.4$ generated a fragment ion of $\mathrm{m} /$ $z 614.3$ corresponding to loss of a molecule of water and a $b_{1}$ ion of $\mathrm{m} / z 504.3$ corresponding to loss of a lysine residue; cleavage at sulfur produced a fragment ion of the $\mathrm{m} / z 417.3$ ion (Fig. 1). These data support modification at Cys-101 by IAtag. MS-MS with CID of the ion of $m / z$ 732.0 produced a series of $b$ - and y-ions (Fig. 1) corresponding to the fragments of ASCLYGQLPK-tag and confirming Cys-47 modification.

\section{Model Protein Oxidation}

Western blots and densitometric analysis of incubations containing increasing amounts of $\mathrm{H}_{2} \mathrm{O}_{2}$ showed reduced labeling of hGST P1-1 $(0.05 \mathrm{mg} / \mathrm{mL})$ by the IAtag $(50 \mu \mathrm{M})$, as expected due to cysteine oxidation (Fig. 2). Similarly, oxidation or adduction of cysteine residues by a quinoid metabolite would be expected to be manifested by a loss of intensity of the IAtagged protein in the western blot. In confirmation, incubation of hGST P1-1 with nanomolar to micromolar concentrations of the equine estrogen metabolite, 4-OHEN, resulted in reduced IAtagged protein (Fig. 2). This result is consistent with previous reports of oxidation and covalent modification of proteins including hGST P1-1 by 4-OHEN (27). No evidence of Soxidation of biotin itself was observed under these conditions, that might perturb the analysis, in accord with a previous report (16).

\section{Proof-of-principle II: model protein modification by COATag}

Mushroom tyrosinase (monophenol monooxygenase EC 1.14.18.1) is a dinuclear copper dependent oxidoreductase capable of oxidizing phenolic substrates to quinoids. Incubation of tyrosinase with either IAtag or the COATag gave no clearly visible bands in western blot analysis using HRP-streptavidin at the tyrosinase concentrations used in this study, whereas co-incubation of hGST P1-1with tyrosinase and raloxifene COATag $(30 \mu \mathrm{M})$ led to the covalent modification of hGST P1-1 $(0.2 \mu \mathrm{g} / \mathrm{mL})$, in a manner dependent on the amount of 
tyrosinase and on the incubation time (Fig. 2). Incubation of hGST P1-1 with the COATag in the absence of tyrosinase gave no reaction.

LC-MS-MS analysis of the raloxifene COATagged peptides, after tryptic digestion and concentration on avidin beads, showed that hGST P1-1was selectively modified at Cys-47, yielding the modified peptide fragment of $\mathrm{m} / z 911$ (ASC(COATag)LYGQLPK). Analysis of this fragment by LC-MS-MS with CID produced the abundant complementary product ions of $\mathrm{m} / \mathrm{z} 503$ and $\mathrm{m} / \mathrm{z} 1318$ (Fig. 3). The product ion of $\mathrm{m} / \mathrm{z} 503$ corresponded to fragmentation of the raloxifene COATag, and was also observed in the MS-MS spectrum of the raloxifene COATag alone. Selective monitoring of this product ion, or alternatively neutral loss of the fragment, therefore provide methods for detection of COATagged peptide fragments. A series of $b$-ions $\left(b_{5}, b_{7}\right.$, and $\left.b_{8}\right)$ expected for the modified peptide ion were detected using MS-MS which were shifted by +742 , corresponding to the mass of the COATag; and $y$-ions ( $y_{3}$ and $\mathrm{y}_{5}$ ), were also observed confirming the peptide sequence (Fig. 3). In order to verify that modification of hGST P1-1 was selective for Cys-47, LC-MS-MS with constant neutral loss monitoring for elimination of the tag $\left([\mathrm{MH}-503]^{+}\right)$was carried out on the peptide digest: only one peptide was detected at $45.1 \mathrm{~min}$ corresponding to [ASC ${ }_{47} \mathrm{LYGQLPK]-raloxifene}$ COATag. As observed with the IAtag, extended co-incubations of hGST P1-1 with the COATag will yield modification of further cysteine residues.

\section{Proof-of-principle III: modification of tissue proteins by COATag}

The cytochrome $\mathrm{P} 450$-mediated bioactivation of raloxifene has been proposed to be catalyzed by P450 3A isozymes $(8,13)$. Therefore, microsomes $(1.5 \mathrm{mg} / \mathrm{mL})$ isolated from rats which were treated with dexamethasone to induce $\mathrm{P} 4503 \mathrm{~A}$ isozymes were used as a model system to identify the target proteins of raloxifene in the liver. Western blots of microsomal incubations of raloxifene COATag $(30 \mu \mathrm{M})$ with an NADPH-generating system showed concentration dependence of protein modification on added NADP+ (Fig. 4A). Similar results were obtained with direct addition of NADPH (Fig 4B). In both experiments, low level modification of proteins $(\sim 60 \mathrm{kDa})$ was observed without addition of cofactors, compatible with basal oxidative activity that is not nicotinamde cofactor dependent.

In order to identify the major microsomal protein targets, the raloxifene COATagged peptides were concentrated by using immobilized avidin. The efficiency of this enrichment and the degree of protein modification by raloxifene COATag is seen by comparison with the protein content of the PBS avidin eluate (Fig. 5A, B; lane b) and the biotin-displaced avidin eluate (Fig. 5A, B; lane c). The non-specific retention of un-COATagged proteins on the avidin beads is a possibility that was addressed by running control reactions of microsomal incubations in the absence of the COATag. Control reactions that used avidin washing by PBS, followed by protein elution using a biotin eluant, did show very low level retention on avidin of some protein bands. Washing with PBS, of higher ionic strength and containing surfactant, was successful in removing all unmodified protein that was visible using Coomassie blue staining (Fig. 5C, lane b), but also resulted in elution and loss of COATagged protein. Clearly, the intelligent use of elution conditions is indicated in order to support the identification of avidin-captured proteins as being covalently modified.

On the basis of avidin capture and western blots, two major microsomal protein bands were identified (Fig 5A,B) and constituent proteins were analyzed by mass spectroscopy. For this proof-of-principle study, after in gel digestion, two methods of mass mapping of digested peptide fragments were selected: (1) MALDI-TOF analysis of band 1 proteins; and (2) electrospray MS-MS analysis of band 2 proteins. Two proteins were rigorously identified in the MALDI-TOF experiments using duplicate analyses (see Supporting Information), based upon peptide matching, protein coverage (Table 1) and the excellent matching of all major fragments in the MALDI-TOF spectrum (Fig. 6). LC-MS-MS peptide mass mapping is seen 
as a more rigorous technique for protein identification, which on the basis of probability scores indicated two proteins in band 2 (Table 1 and Supporting Information).

Mass spectrometric analysis of the two major protein bands identified four proteins; GRP78 (band 1); protein disulfide isomerase isozyme A4 (72 $\mathrm{kDa}, \mathrm{ERp}-72$, band 1); protein disulfide isomerase isozyme $\mathrm{A} 1$ ( $57 \mathrm{KDa}$, PDIA1, band 2); and protein disulfide isomerase isozyme A3 (57 kDa, ER60, band 2). The identity of GRP78 was confirmed by immunolabeling with antiGRP 78 polyclonal antibody (20). Furthermore, microsomal GST 1 (mGST1) was identified by immunolabeling of the raloxifene COATagged microsomal proteins with anti-mGST1 Ab after concentration on immobilized avidin (Fig. 5 D and band 3 in Fig. 5 A) (22). A further control reaction was performed using anti-mGST1 to test for non-specific retention of mGST1 by avidin, which was negative within the detection limits of the immunoblot. Experiments with a P450 3A1 mAb (Oxford Biomedical Research, Research, Oxford, MI) showed no immunoreactivity towards COATagged proteins concentrated from the microsomal milieu using avidin beads.

\section{DISCUSSION}

Both HRT and SERM therapy target estrogen receptors to modulate estrogenic activity, either through antiestrogenic effects in treating and/or preventing breast cancer or through proestrogenic effects supplementing natural estrogens in perimenopausal and postmenopausal conditions. Since many such therapies entail long-term drug treatment, and because of demonstrated health risks associated with the drugs themselves, including carcinogenesis, extensive study of potential toxic mechanisms is vital $(1,4,5,7,28)$. The constituents of HRT agents and many SERMs are polyaromatic phenols (Scheme 1). The prototypical SERM, tamoxifen, is oxidized by cytochrome P450 to the polyaromatic phenolic active metabolite, 4hydroxytamoxifen, that is further oxidized to quinoids (29). Similarly, equilenin, raloxifene, acolbifene, and arzoxifene are bioactivated to quinoid metabolites that have been shown to form adducts with GSH and nucleic acids $(8,11,13,30)$. Quinoid reactive intermediates are able both to act as electrophilic Michael-type acceptors towards cellular nucleophiles and to redox cycle leading to depletion of cellular reductants and generation of reactive oxygen species (ROS) (31).

Covalent modification of proteins by quinoids and other reactive intermediates, formed from xenobiotics, is usually regarded as undesirable. Detrimental, functional consequences potentially include disruption of enzyme activity, gene transcription, cell signaling, protein turnover, and cytoskeletal integrity $(17,18)$. However, protein modification may also result in induction of stress response, defense mechanisms that may represent chemopreventive pathways. The identification of covalently modified proteins is essential before the functional consequences of such modification can be examined.

Traditionally, radiolabled substrates have been used to identify alkylated proteins. For example, radiolabeled proteins, including those tentatively identified as P450's, were detected in human liver microsomes treated with radiolabeled tamoxifen (32). Direct addition of the radiolabeled 3,4-catechol metabolite confirmed P450 modification in liver microsomes, and suggested that other proteins might also be modified (33). In response to the inherent limitations of the radiolabeling technique, direct mass spectrometric evidence was recently sought and obtained for the covalent modification of cytochrome P450 3A4 by two model xenobiotics (14).

Recently, strategies have been reported, consisting of biotin-linked electrophiles used to tag and identify proteins, and estrogens derivatized to covalently modify nucleic acids (34-36). Several probes are commercially available in which a thiol-directed electrophile is linked to 
biotin, such as the iodoacetamide "IAtag" used in this study. These probes are intrinsically reactive electrophiles that will covalently tag cysteine residues, however, a COATag (covert oxidatively activated tag) is a biotin-linked xenobiotic that is not an intrinsic electrophile, but which requires bioactivation. A COATag of the SERM raloxifene was selected for this proofof-principle study. The COATag is predicted to be unreactive towards cellular nucleophiles without oxidative activation by cellular constituents. Exploitation of the high affinity recognition of immobilized avidin for biotin facilitates trapping and enrichment of tagged proteins; the use of streptavidin-HRP (or anti-biotin-HRP) facilitates sensitive quantitation of modified protein (Scheme 2) (37). A COATag may therefore be used as a probe of protein covalent modification.

Xenobiotics, such as raloxifene, that do not possess a convenient carboxylate or amino group suitable for trivial conjugation to commercially available biotin tags, require de novo synthesis of COATags; this was achieved in the case of raloxifene by substitution of the piperidyl by an amino group (Scheme 3). Factors in COATag design include the properties of the linker moiety (which should be insensitive to bioactivation) and minimizing the disruption of the metabolic and oxidative reactivity of the parent xenobiotic. The SERMs, including raloxifene, are particularly attractive candidates for the COATag approach, because the amine side chain provides a site of modification that is remote from the polyaromatic phenolic moiety that is susceptible to oxidative metabolism to a quinoid. All preliminary data are compatible with similar oxidative metabolic profiles for raloxifene and its COATag, at least in liver microsomes. It was postulated that COATag activation by innate cellular oxidative systems would lead to covalent protein modification, but unanswered questions remained over the identity of the proteins and over the reactivity, diffusion, and localization of short-lived, xenobiotic-derived reactive intermediates.

The hypothesis posits that (1) protein modification by the raloxifene COATag would occur only in the presence of an oxidizing system; in contrast (2) protein modification by IAtag would be reduced in the presence of an oxidizing system that results in protein thiol oxidation (16, 38). 4-OHEN, a major phase I catechol metabolite of the equine estrogens equilenin and equilin, has been shown to oxidize, covalently modify, and inactivate several phase I and phase II enzymes including hGST P1-1 (27); an enzyme of relevance to detoxification of xenobiotics and endogenous catechols and quinoids (39). As a result, hGST P1-1 was chosen as a model protein to study covalent modification and protein oxidation, using the IAtag and the novel raloxifene COATag as probes.

Incubation of hGST P1-1 with both millimolar $\mathrm{H}_{2} \mathrm{O}_{2}$ and micromolar 4-OHEN led to concentration dependent modification of protein thiols as quantified by the IAtag (Fig. 2). As shown by our previous work, 4-OHEN modifies hGST P1-1 protein cysteine residues by oxidation and alkylation (27). 4-OHEN autoxidizes in aerobic solution with a half-life of 4 min, yielding superoxide and $o$ - quinone; the latter is able to alkylate and oxidize thiol groups and to redox cycle (9). Although, we have shown that raloxifene can be oxidized by tyrosinase and by liver microsomes to a di-quinone that is trapped by GSH, raloxifene does not readily form $o$-quinones (40). Moreover, unlike 4-OHEN, raloxifene does not readily autoxidize to a quinoid reactive intermediate, and therefore raloxifene alone does not modify hGST P1-1.

Incubation of hGST P1-1 with raloxifene COATag in the presence of tyrosinase led to covalent modification of hGST P1-1 with dependence on incubation time and tyrosinase concentration (Fig. 2). Subsequent LC-MS-MS analysis showed that the raloxifene COATagged protein was modified selectively at Cys-47 (Fig. 3), whereas IAtagged protein, similarly analyzed, was selectively modified at Cys-47 and Cys-101 (Fig. 1). This is consistent with literature reports that Cys-47 is the most reactive sulfhydryl group towards covalent modification (26). Based upon previous studies with raloxifene, the site of attack on raloxifene, itself, by protein thiol 
is expected to be C7 of the benzothiophene ring (40,41). LC-MS-MS analysis of incubations of hGST P1-1 with tyrosinase and raloxifene, itself, showed qualitatively the same behaviour (data not shown), suggesting that the biotin-linker moiety does not have a significant influence on reactivity. The observations with GST P1-1 demonstrate that the combination of oxidative enzyme (i.e tyrosinase) with a COATag allows identification of sites of protein modification by oxidatively labile xenobiotics using mass spectrometric analysis. The raloxifene COATag facilitates the observation and quantitation of labeled protein via western blot in addition to enrichment of modified protein for improved mass spectrometric analysis using avidin capture, but these benefits are best realized in a more complex biological milieu, such as tissue microsomes.

A dexamethasone-induced rat liver microsomal preparation was selected because of the enrichment of the P450 3A isoform in this preparation and the know activity of cytochrome P450 3A towards raloxifene oxidative bioactivation $(13,40)$. Microsomal incubation of the COATag resulted in basal low level protein modification (possibly associated with a peroxidase activity), with an NADPH-dependent microsomal oxidase activity substantially increasing the level of protein modification (Fig. 4). The concentration dependence of the amount of modified protein upon NADPH, the cofactor required for cytochrome P450 oxidase catalysis, suggests that this enzyme is largely responsible for oxidative activation.

The COATag allows capture and concentration of modified proteins on avidin beads; the integrity of which was tested by appropriate control experiments (Fig. 5). Analysis of the most intense protein bands by western blotting and dye staining identified two overlapping proteins in each band (Fig. 5). After avidin capture, digestion, and mass spectrometric analysis of the microsomal proteins (Scheme 2), these two bands and a further protein band were analyzed leading to identification of five proteins covalently modified by the raloxifene COATag (Table 1). A variety of methods were used to provide proof-of-principle for the COATag methodology: (1) band 1 was interrogated by MALDI-TOF, yielding identification of two proteins; (2) the identity of one of the proteins in band 1 was confirmed by a specific antibody; (3) two proteins were identified in band 2 using LC-MS-MS peptide mass mapping; and, (4) one protein was identified in band 3 using a specific antibody alone.

Two proteins were identified in Band 1: Erp72 and GRP 78 (Table 1). ERp72 (PDIA4) is a protein disulfide isomerase (PDI)/thioredoxin family protein, which possesses significant redox and disulfide-isomerase activity and is an abundant, stress-inducible, calcium-binding protein $(42,43)$. It is known to be covalently modified by a variety of xenobiotics $(44,45)$. GRP78 (BiP) is a nonglycosylated ER-resident protein that is involved in polypeptide translocation, protein glycosylation, protein folding, and membrane protein assembly $(42,46)$. GRP78 has ATPase activity that is coupled to the protein folding and chaperone activities. One cysteine residue is located in the $\mathrm{C} 30$ peptide recognition domain and one in the ATPase active site. GRP78 is related to the hsp70 family of heat shock proteins and is constitutive in all eukaryotic cells, but is upregulated and activated in response to cellular insults, including heavy metals, alkylating agents, and other factors. GRP78 levels have been shown to be a reliable biomarker of hypoglycemia (47) as well as serving a neuroprotective function in neurons exposed to glutamate and oxidative stress (48). Induction of GRP78 is a cellular defense mechanism, providing subsequent protection against oxidative and other stresses. However, protein induction concomitant with loss of function by protein covalent modification will diminish cellular protection. In addition, the induction of GRP78 has been associated with the development of drug resistance to antitumor agents (49).

Two proteins were identified in band 2 (Fig. 5, Table 1). The $57 \mathrm{kDa}$ PDI A1 is a major component of the endoplasmic reticulum (ER) comprising 3-5\% of microsomal protein which serves a number of functions including catalysis of disulfide-bond formation $(42,43)$. PDI 
proteins catalyze thiol-disulfide exchange reactions leading to disulfide bond formation, isomerization, or reduction of substrate proteins. (50) Rat PDI A1 contains six cysteine residues and has four thioredoxin-fold domains, the latter containing two redox-sensitive dithiol/ disulfide CGHC sequences. $(42,46,51)$ Each CGHC sequence provides one highly reactive thiolate site that will be reactive towards either alkylation or oxidation.

The $57 \mathrm{kDa}$ ER60 (ERp60, PDI A3) ER-resident protein is a member of the PDI/thioredoxin family that resembles PDIA1 in size. ER60 has seven cysteine residues, including two thioredoxin-family, CGHC dithiol active site domains like PDI A1. ER60 is multifunctional, and acts as a disulfide isomerase and $\mathrm{Ca}^{2+}$ dependent chaperone or antichaperone in protein binding and folding. (52) The PDI family proteins are common in the lumen of the ER and have also shown protein cross-linking activity.

The use of specific antibodies to identify raloxifene COATagged proteins enriched by use of immobilized avidin is an additional use of the raloxifene COATag technology. The identity of GRP78 in Band 1 was confirmed by use of anti-GRP78. Furthermore, the relatively weak band corresponding to a $17 \mathrm{kDa}$ protein was identified as microsomal glutathione S-transferase-1 (mGST1, 17 kDa) by use of anti-mGST1 (Fig. 5). The reaction of the raloxifene COATag with mGST1 was expected on the basis of the abundance of this protein in rat liver microsomes and its function in xenobiotic binding and detoxification. mGST1 is involved in cellular defense against toxic, carcinogenic, and pharmacologically active electrophilic compounds and catalyzes the conjugation of glutathione to electrophiles and the reduction of lipid hydroperoxides. This protein is localized to the ER and outer mitochondrial membrane where it is thought to protect these membranes from oxidative stress.

The five proteins identified as liver microsomal targets for quinoid metabolites of raloxifene, formed by microsomal NADPH-dependent oxidation, are all relatively abundant in the ER. The three proteins of the PDI/thioredoxin family are also rich in reactive thiolate and dithioldisulfide sites. The fact that modified mGST was observed, confirmed our hypothesis that mGST plays a role in the detoxification of raloxifene metabolites and also serves as a target protein. However, the cytochrome P450 3A isozyme, known to oxidize raloxifene leading to suicide inhibition, was not identified as a modified protein, by either MS-MS analysis or immunoassay with an anti-P450 3A1 antibody. Since this isozyme is known to be inactivated in vitro by raloxifene (13), it is possible that oxidation at the active site results from ROS generated by the quinoid metabolites, but further study with purified protein is indicated.

Although this study was designed to obtain proof-of principle, several interesting observations are made. Protein selectivity for covalent modification can be dictated by both protein concentration and the availability of reactive thiolate residues; however, features of the xenobiotic reactive intermediate are also factors, including the lifetime, the cellular localization, specific protein binding, and the intrinsic rate of reaction of the reactive intermediate with protein thiols. The observation that raloxifene covalently modifies a number of liver microsomal proteins clearly confirms that the quinoid intermediates are of sufficient lifetime to diffuse from the protein responsible for their formation (presumably P450 3A isozymes). The raloxifene diquinone methide is short-lived $\left(\mathrm{t}_{1 / 2}<1 \mathrm{~s}\right)$ relative to related quinoids (diquinone methides, quinone methides and $o$-quinones) $(31,40)$; for example, the quinone methide from 4-HO-tamoxifen has a half life of several hours (53). The reactivity of the raloxifene diquinone is therefore predicted to be of low selectivity. Qualitative comparison of unmodified microsomal proteins with COATagged proteins does suggest that the raloxifene COATag is poorly selective, reacting with the most abundant microsomal proteins (compare lanes $\mathrm{c}$ and $\mathrm{d}$ of Fig. 5C, respectively). 
An intuitively attractive theory has been postulated based upon correlation of reactivity versus cytotoxicity of quinone methides, whereby: (a) short-lived, reactive electrophiles are expected not to be selective in their reactivity and to react with the progenitor oxidative enzyme or with solvent; whereas (b) long-lived species are expected to be reactive only to activated systems designed for detoxification. Thus, cytotoxicity was predicted for species with intermediate in vivo half life (10s $\left.<\mathrm{t}_{1 / 2}<10 \mathrm{~min}\right)(54)$. The use of COATags will clarify and refine this postulate, but even the short-lived raloxifene quinone methide is clearly able to diffuse sufficiently to allow reaction with a variety of proteins in the microsomal milieu. These preliminary data predict that other SERMs and HRT components such as equine estrogens will readily cause protein modification.

A large number of proteins have been identified as targets for hepatotoxic xenobiotics, mostly from studies with halothane, acetaminophen, and bromobenzene, the latter two forming quinoids responsible for protein modification. $(42,44,55)$ Among the proteins identified as targets for raloxifene, PDIA1 is also a target for all three aforementioned xenobiotics, PDI A3 adducts with acetaminophen and bromobenzene have been reported, and GRP78 was shown to be modified by halothane and bromobenzene. Protein covalent modification has been implicated in the toxicity of various hepatotoxins; and modification of essential thiol residues will inhibit protein function. Conversely, xenobiotics that form reactive intermediates capable of alkylation and oxidation of thiol groups on sensor proteins, such as Keap1, are able to induce cellular defense pathways, such as those elicited via the antioxidant response element (ARE). $(19,56)$ Keap1 acts as a sensor protein for oxidative/electrophilic stress, is induced by electrophilic Michael acceptors (of which quinone methides are an example), and is a drug target for chemopreventive agents. Identification of the proteins modified by xenobiotic reactive intermediates is essential to define cytoprotective, chemopreventive, and cytotoxic activity. In the case of equilenin and the SERMs that are readily oxidized to quinoid metabolites and are intended for long-term use, identification of protein targets is especially important and greatly facilitated by the COATag methodology as demonstrated herein.

\section{Supplementary Material}

Refer to Web version on PubMed Central for supplementary material.

\section{Acknowledgements}

This work was supported by NIH grants CA 79870 and CA 102590. We thank Dr. Brian Bennett (Queen's University) and Dr. Sylvie Blond (UIC) for providing mGST and GRP78 antibodies, respectively.

\section{References}

1. Rossouw JE, Anderson GL, Prentice RL, LaCroix AZ, Kooperberg C, Stefanick ML, Jackson RD, Beresford SA, Howard BV, Johnson KC, Kotchen JM, Ockene J. Risks and benefits of estrogen plus progestin in healthy postmenopausal women: principal results From the Women's Health Initiative randomized controlled trial. J. Am. Med. Assoc 2002;288:321-333.

2. Delmas PD, Bjarnason NH, Mitlak BH, Ravoux AC, Shah AS, Huster WJ, Draper M, Christiansen C. Effects of raloxifene on bone mineral density, serum cholesterol concentrations, and uterine endometrium in postmenopausal women. N. Engl. J. Med 1997;337:1641-1647. [PubMed: 9385122]

3. Fisher B, Costantino JP, Wickerham DL, Redmond CK, Kavanah M, Cronin WM, Vogel V, Robidoux A, Dimitrov N, Atkins J, Daly M, Wieand S, Tan-Chiu E, Ford L, Wolmark N. Tamoxifen for prevention of breast cancer: report of the National Surgical Adjuvant Breast and Bowel Project P-1 Study. J. Natl. Cancer Inst 1998;90:1371-1388. [PubMed: 9747868]

4. King CM. Tamoxifen and the induction of cancer. Carcinogenesis 1995;16:1449-1454. [PubMed: 7614676] 
5. van Leeuwen FE, Benraadt J, Coebergh JW, Kiemeney LA, Gimbráere CH, Otter R, Schouten LJ, Damhuis RA, Bontenbal M, Diepenhorst FW, et al. Risk of endometrial cancer after tamoxifen treatment of breast cancer. Lancet 1994;343:448-452. [PubMed: 7905955]

6. Zhang F, Fan PW, Liu X, Shen L, van Breemen RB, Bolton JL. Synthesis and reactivity of a potential carcinogenic metabolite of tamoxifen: 3,4-dihydroxytamoxifen-o-quinone. Chem. Res. Toxicol 2000;13:53-62. [PubMed: 10649967]

7. Shibutani S, Ravindernath A, Suzuki N, Terashima L, Sugarman SM, Grollman AP, Pearl ML. Identification of tamoxifen-DNA adducts in the endometrium of women treated with tamoxifen. Carcinogenesis 2000;21:1461-1467. [PubMed: 10910945]

8. Yu L, Liu H, Li W, Zhang F, Luckie C, van Breemen RB, Thatcher GRJ, Bolton JL. Oxidation of raloxifene to quinoids: potential toxic pathways via a diquinone methide and o-quinones. Chem. Res. Toxicol 2004;17:879-888. [PubMed: 15257612]

9. Shen L, Pisha E, Huang Z, Pezzuto JM, Krol E, Alam Z, van Breemen RB, Bolton JL. Bioreductive activation of catechol estrogen-ortho-quinones: aromatization of the B ring in 4-hydroxyequilenin markedly alters quinoid formation and reactivity. Carcinogenesis 1997;18:1093-1101. [PubMed: 9163701]

10. Han X, Liehr JG. Microsome-mediated 8-hydroxylation of guanine bases of DNA by steroid estrogens: correlation of DNA damage by free radicals with metabolic activation to quinones. Carcinogenesis 1995;16:2571-4. [PubMed: 7586168]

11. Liu J, Liu H, van Breemen RB, Thatcher GR, Bolton JL. Bioactivation of the selective estrogen receptor modulator acolbifene to quinone methides. Chem Res Toxicol 2005;18:174-82. [PubMed: 15720121]

12. Liu H, Liu J, van Breemen RB, Thatcher GR, Bolton JL. Bioactivation of the selective estrogen receptor modulator desmethylated arzoxifene to quinoids: 4'-fluoro substitution prevents quinoid formation. Chem Res Toxicol 2005;18:162-73. [PubMed: 15720120]

13. Chen Q, Ngui JS, Doss GA, Wang RW, Cai X, DiNinno FP, Blizzard TA, Hammond ML, Stearns RA, Evans DC, Baillie TA, Tang W. Cytochrome P450 3A4-mediated bioactivation of raloxifene: irreversible enzyme inhibition and thiol adduct formation. Chem. Res. Toxicol 2002;15:907-914. [PubMed: 12119000]

14. Bateman KP, Baker J, Wilke M, Lee J, Leriche T, Seto C, Day S, Chauret N, Ouellet M, NicollGriffith DA. Detection of covalent adducts to cytochrome P450 3A4 using liquid chromatography mass spectrometry. Chem. Res. Toxicol 2004;17:1356-1361. [PubMed: 15487896]

15. Zhou S, Chan E, Duan W, Huang M, Chen YZ. Drug bioactivation, covalent binding to target proteins and toxicity relevance. Drug Metab Rev 2005;37:41-213. [PubMed: 15747500]

16. Kim JR, Yoon HW, Kwon KS, Lee SR, Rhee SG. Identification of proteins containing cysteine residues that are sensitive to oxidation by hydrogen peroxide at neutral $\mathrm{pH}$. Anal. Biochem 2000;283:214-221. [PubMed: 10906242]

17. Evans DC, Watt AP, Nicoll-Griffith DA, Baillie TA. Drug-protein adducts: an industry perspective on minimizing the potential for drug bioactivation in drug discovery and development. Chem. Res. Toxicol 2004;17:3-16. [PubMed: 14727914]

18. Cohen SD, Pumford NR, Khairallah EA, Boekelheide K, Pohl LR, Amouzadeh HR, Hinson JA. Selective protein covalent binding and target organ toxicity. Toxicol. Appl. Pharmacol 1997;143:112. [PubMed: 9073586]

19. Wakabayashi N, Dinkova-Kostova AT, Holtzclaw WD, Kang MI, Kobayashi A, Yamamoto M, Kensler TW, Talalay P. Protection against electrophile and oxidant stress by induction of the phase 2 response: fate of cysteines of the Keap1 sensor modified by inducers. Proc Natl Acad Sci U S A 2004;101:2040-5. [PubMed: 14764894]

20. Chang M, Bolton JL, Blond SY. Expression and purification of hexahistidine-tagged human glutathione S-transferase P1-1 in Escherichia coli. Protein Expr Purif 1999;17:443-8. [PubMed: 10600464]

21. Chevalier M, King L, Blond S. Purification and properties of BiP. Methods Enzymol 1998;290:384409. [PubMed: 9534177]

22. Ji Y, Toader V, Bennett BM. Regulation of microsomal and cytosolic glutathione S-transferase activities by S-nitrosylation. Biochemical Pharmacology 2002;63:1397-1404. [PubMed: 11996880] 
23. Thompson JA, Malkinson AM, Wand MD, Mastovich SL, Mead EW, Schullek KM, Laudenschlager WG. Oxidative metabolism of butylated hydroxytoluene by hepatic and pulmonary microsomes from rats and mice. Drug Metab. Dispos 1987;15:833-840. [PubMed: 2893710]

24. Landry F, Lombardo CR, Smith JW. A method for application of samples to matrix-assisted laser desorption ionization time-of-flight targets that enhances peptide detection. Anal. Biochem 2000;279:1-8. [PubMed: 10683224]

25. Nishihira J, Ishibashi T, Sakai M, Nishi S, Kumazaki T, Hatanaka Y, Tsuda S, Hikichi K. Characterization of cysteine residues of glutathione S-transferase P: evidence for steric hindrance of substrate binding by a bulky adduct to cysteine 47. Biochem. Biophys. Res. Commun 1992;188:424432. [PubMed: 1417864]

26. Lo Bello M, Petruzzelli R, De Stefano E, Tenedini C, Barra D, Federici G. Identification of a highly reactive sulphydryl group in human placental glutathione transferase by a site-directed fluorescent reagent. FEBS Lett 1990;263:389-391. [PubMed: 2335245]

27. Chang M, Shin YG, van Breemen RB, Blond SY, Bolton JL. Structural and functional consequences of inactivation of human glutathione S-transferase P1-1 mediated by the catechol metabolite of equine estrogens, 4-hydroxyequilenin. Biochemistry 2001;40:4811-20. [PubMed: 11294649]

28. Hemminki K, Rajaniemi H, Lindahl B, Moberger B. Tamoxifen-induced DNA adducts in endometrial samples from breast cancer patients. Cancer Res 1996;56:4374-4377. [PubMed: 8813128]

29. Fan PW, Zhang F, Bolton JL. 4-Hydroxylated metabolites of the antiestrogens tamoxifen and toremifene are metabolized to unusually stable quinone methides. Chem. Res. Toxicol 2000;13:4552. [PubMed: 10649966]

30. Zhang F, Chen Y, Pisha E, Shen L, Xiong Y, van Breemen RB, Bolton JL. The major metabolite of equilin, 4-hydroxyequilin, autoxidizes to an o-quinone which isomerizes to the potent cytotoxin 4hydroxyequilenin-o-quinone. Chem. Res. Toxicol 1999;12:204-213. [PubMed: 10027800]

31. Bolton JL, Yu L, Thatcher GR. Quinoids formed from estrogens and antiestrogens. Methods Enzymol 2004;378:110-23. [PubMed: 15038960]

32. Dehal SS, Kupfer D. Cytochrome P-450 3A and 2D6 catalyze ortho hydroxylation of 4hydroxytamoxifen and 3-hydroxytamoxifen (droloxifene) yielding tamoxifen catechol: involvement of catechols in covalent binding to hepatic proteins. Drug Metab. Dispos 1999;27:681-688. [PubMed: 10348797]

33. Mani C, Kupfer D. Cytochrome P-450-mediated activation and irreversible binding of the antiestrogen tamoxifen to proteins in rat and human liver: possible involvement of flavin-containing monooxygenases in tamoxifen activation. Cancer Res 1991;51:6052-6058. [PubMed: 1933868]

34. Kumar S, Zhou B, Liang F, Wang WQ, Huang Z, Zhang ZY. Activity-based probes for protein tyrosine phosphatases. Proc. Natl. Acad. Sci. U S A 2004;101:7943-7948. [PubMed: 15148367]

35. Kidd D, Liu Y, Cravatt BF. Profiling serine hydrolase activities in complex proteomes. Biochemistry 2001;40:4005-15. [PubMed: 11300781]

36. Mitra K, Marquis JC, Hillier SM, Rye PT, Zayas B, Lee AS, Essigmann JM, Croy RG. A rationally designed genotoxin that selectively destroys estrogen receptor-positive breast cancer cells. J Am Chem Soc 2002;124:1862-3. [PubMed: 11866593]

37. Graf R, Friedl P. Detection of immobilized proteins on nitrocellulose membranes using a biotinylation-dependent system. Anal. Biochem 1999;273:291-297. [PubMed: 10469500]

38. Suh SK, Hood BL, Kim BJ, Conrads TP, Veenstra TD, Song BJ. Identification of oxidized mitochondrial proteins in alcohol-exposed human hepatoma cells and mouse liver. Proteomics 2004;4:3401-12. [PubMed: 15449375]

39. Prestera T, Holtzclaw WD, Zhang Y, Talalay P. Chemical and molecular regulation of enzymes that detoxify carcinogens. Proc. Natl. Acad. Sci. U S A 1993;90:2965-2969. [PubMed: 8385353]

40. Yu L, Liu H, Li W, Zhang F, Luckie C, Van Breemen RB, Thatcher GRJ, Bolton JL. Oxidation of raloxifene to quinoids: potential toxic pathways via a diquinone methide and o-quinones. Chem Res Toxicol 2004;17:879-88. [PubMed: 15257612]

41. Toader V, Xu X, Nicolescu A, Yu L, Bolton JL, Thatcher GR. Nitrosation, nitration, and autoxidation of the selective estrogen receptor modulator raloxifene by nitric oxide, peroxynitrite, and reactive nitrogen/oxygen species. Chem Res Toxicol 2003;16:1264-76. [PubMed: 14565768] 
42. Koen YM, Hanzlik RP. Identification of seven proteins in the endoplasmic reticulum as targets for reactive metabolites of bromobenzene. Chem. Res. Toxicol 2002;15:699-706. [PubMed: 12018992]

43. Ferrari DM, Sèoling HD. The protein disulphide-isomerase family: unravelling a string of folds. Biochem. J 1999;339:1-10. [PubMed: 10085220]

44. Zhou L, McKenzie BA, Eccleston ED Jr. Srivastava SP, Chen N, Erickson RR, Holtzman JL. The covalent binding of [14C] acetaminophen to mouse hepatic microsomal proteins: the specific binding to calreticulin and the two forms of the thiol:protein disulfide oxidoreductases. Chem. Res. Toxicol 1996;9:1176-1182. [PubMed: 8902274]

45. Zhou LX, Dehal SS, Kupfer D, Morrell S, McKenzie BA, Eccleston ED Jr. Holtzman JL. Cytochrome P450 catalyzed covalent binding of methoxychlor to rat hepatic, microsomal iodothyronine $5^{\prime}$ monodeiodinase, type I: does exposure to methoxychlor disrupt thyroid hormone metabolism? Arch. Biochem. Biophys 1995;322:390-394. [PubMed: 7574712]

46. Haas IG. BiP (GRP78), an essential hsp70 resident protein in the endoplasmic reticulum. Experientia 1994;50:1012-1120. [PubMed: 7988659]

47. Barnes JA, Smoak IW, Branch S. Expression of glucose-regulated proteins (GRP78 and GRP94) in hearts and fore-limb buds of mouse embryos exposed to hypoglycemia in vitro. Cell Stress Chaperones 1999;4:250-258. [PubMed: 10590839]

48. Katayama T, Imaizumi K, Sato N, Miyoshi K, Kudo T, Hitomi J, Morihara T, Yoneda T, Gomi F, Mori Y, Nakano Y, Takeda J, Tsuda T, Itoyama Y, Murayama O, Takashima A, George-Hyslop P St, Takeda M, Tohyama M. Presenilin-1 mutations downregulate the signalling pathway of the unfolded-protein response. Nat. Cell Biol 1999;1:479-485. [PubMed: 10587643]

49. Koomèagi R, Mattern J, Volm M. Glucose-related protein (GRP78) and its relationship to the drugresistance proteins P170, GST-pi, LRP56 and angiogenesis in non-small cell lung carcinomas. Anticancer Res 1999;19:4333-4336. [PubMed: 10628396]

50. Freedman RB, Hirst TR, Tuite MF. Protein disulphide isomerase: building bridges in protein folding. Trends Biochem. Sci 1994;19:331-336. [PubMed: 7940678]

51. Hawkins HC, Freedman RB. The reactivities and ionization properties of the active-site dithiol groups of mammalian protein disulphide-isomerase. Biochem. J 1991;275:335-339. [PubMed: 2025220]

52. Bennett CF, Balcarek JM, Varrichio A, Crooke ST. Molecular cloning and complete amino-acid sequence of form-I phosphoinositide-specific phospholipase C. Nature 1988;334:268-270. [PubMed: 3398923]

53. Fan PW, Zhang F, Bolton JL. 4-Hydroxylated metabolites of the antiestrogens tamoxifen and toremifene are metabolized to unusually stable quinone methides. Chem Res Toxicol 2000;13:4552. [PubMed: 10649966]

54. Thompson DC, Perera K, Krol ES, Bolton JL. o-Methoxy-4-alkylphenols that form quinone methides of intermediate reactivity are the most toxic in rat liver slices. Chem Res Toxicol 1995;8:323-7. [PubMed: 7578916]

55. Amouzadeh HR, Bourdi M, Martin JL, Martin BM, Pohl LR. UDP-glucose:glycoprotein glucosyltransferase associates with endoplasmic reticulum chaperones and its activity is decreased in vivo by the inhalation anesthetic halothane. Chem. Res. Toxicol 1997;10:59-63. [PubMed: 9074803]

56. Kwak MK, Wakabayashi N, Kensler TW. Chemoprevention through the Keap1-Nrf2 signaling pathway by phase 2 enzyme inducers. Mutat Res 2004;555:133-48. [PubMed: 15476857] 


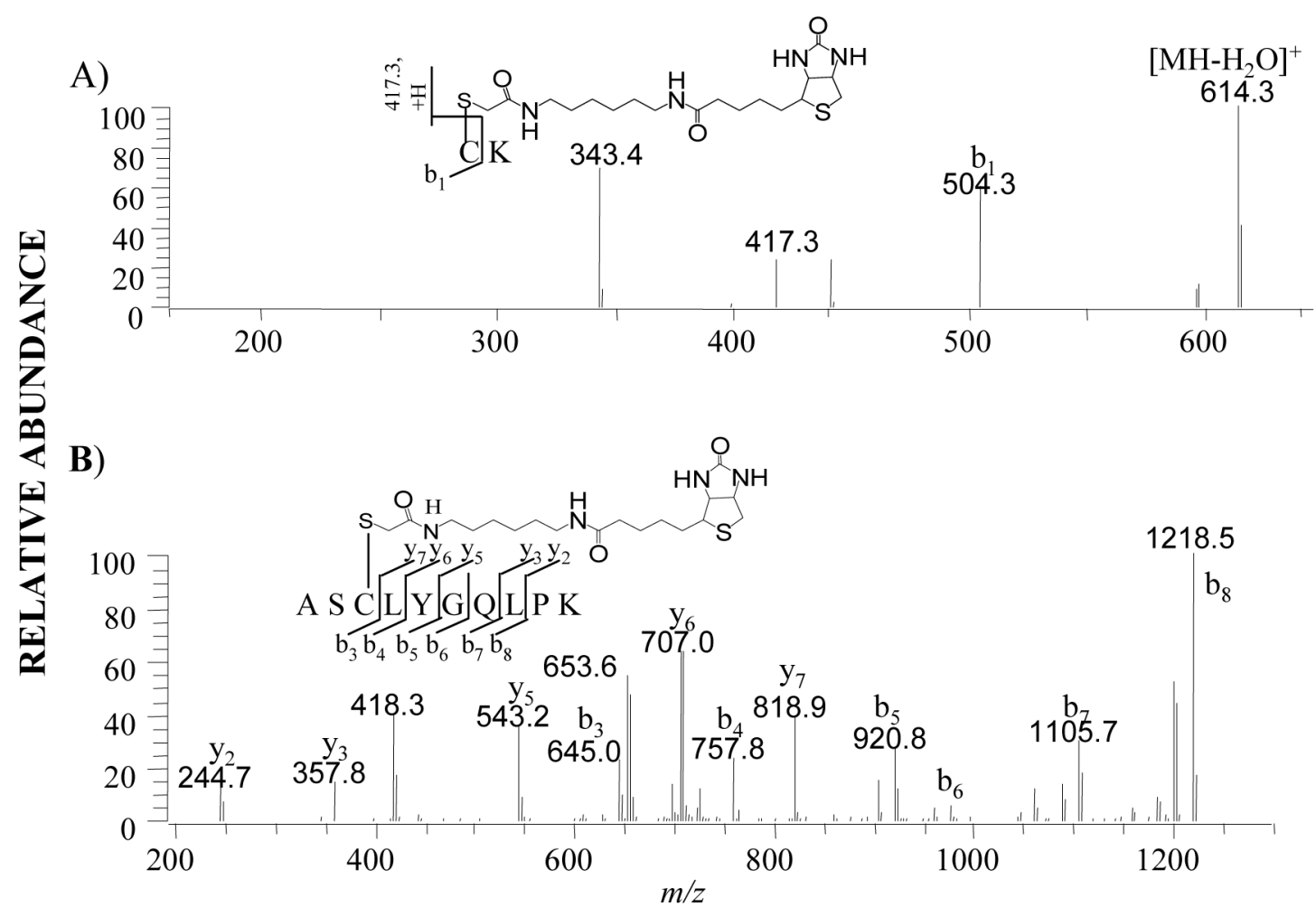

Figure 1.

Positive ion electrospray LC-MS-MS product ion analysis of the modified peptides from tryptic digests of IAtag modified hGST P1-1 after avidin enrichment. After incubation of hGST P1-1 with IAtag as described in the text, the protein mixture $\left(1 \mathrm{mg} / \mathrm{mL}\right.$ in $200 \mu \mathrm{L} \mathrm{NH}_{4} \mathrm{HCO}_{3}$ buffer, $\mathrm{pH}$ 8.5) was digested with trypsin $(1 \mu \mathrm{g})$ overnight at $37^{\circ} \mathrm{C}$. Avidin beads were was used to concentrate only tagged peptide fragments prior to LC-MS-MS. A) Modified peptide: (tag)$\mathrm{C}_{101} \mathrm{~K}$ of $m / z$ 632.4. B) Modified peptide: $\mathrm{ASC}_{47}(\operatorname{tag})$ LYGQLPK of $m / z(\mathrm{z}=2) 732.0$. 
A) $\begin{array}{llllllll}\mathrm{H}_{2} \mathrm{O}_{2}(\mathrm{mM}) & 0 & 0.1 & 0.5 & 1 & 2 & 5 & 10\end{array}$
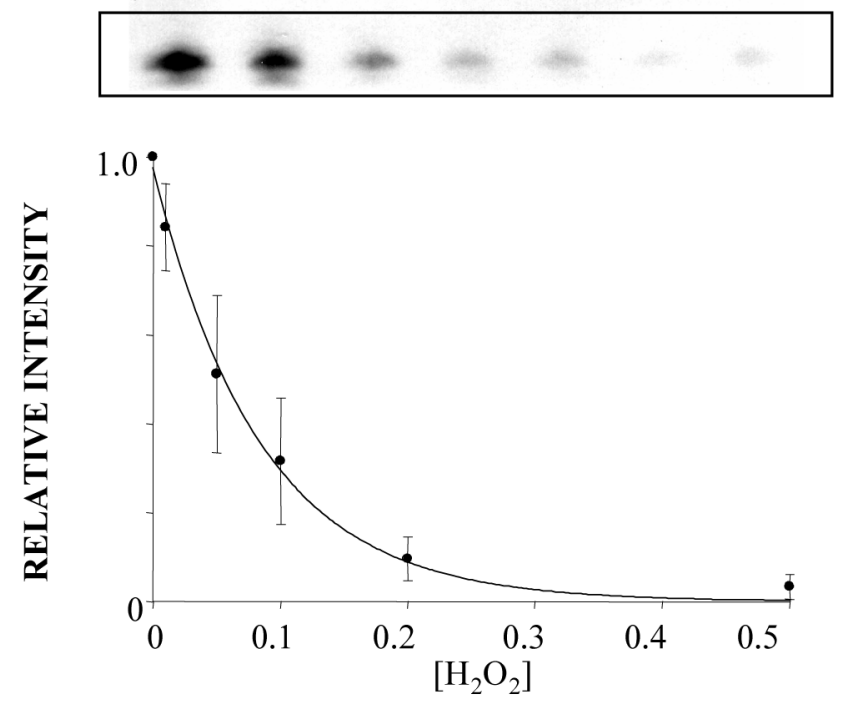

B) 4-OHEN concentration $(\mu \mathrm{M})$

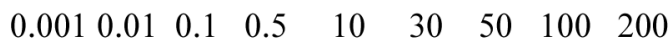

D) Tyrosinase (mg/ mL)

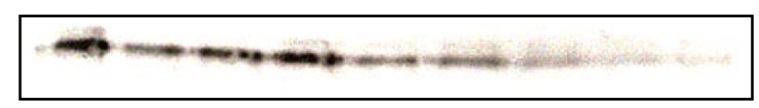

C) Time (min) 4-OHEN

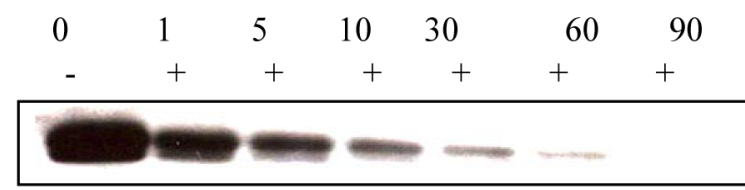

\begin{tabular}{|lllll|}
0.003 & 0.006 & 0.03 & 0.06 & 0.3 \\
\hline & & \\
\hline
\end{tabular}

E) Incubation time

(min)

\begin{tabular}{|llllll|}
0 & 15 & 30 & 60 & 90 & 120 \\
\hline & & & & \\
\hline
\end{tabular}

Figure 2.

Western blot analysis of the modification of hGST P1-1. (A) hGST P1-1 $(0.05 \mathrm{mg} / \mathrm{mL})$ and various concentrations of $\mathrm{H}_{2} \mathrm{O}_{2}$ were preincubated for $10 \mathrm{~min}$ followed by the addition of IAtag $(50 \mu \mathrm{M})$ and incubation for another $30 \mathrm{~min}$. Densitometric quantitation of the IAtagged protein band is plotted against $\mathrm{H}_{2} \mathrm{O}_{2}$ concentration; values represent the means $\pm \mathrm{SD}$ of triplicate determinations (the curve is drawn to aid visualization). (B) hGST P1-1 $(0.05 \mathrm{mg} / \mathrm{mL})$ and various concentrations of 4-OHEN were preincubated for $10 \mathrm{~min}$ followed by the addition of IAtag $(50 \mu \mathrm{M})$ and incubation for another $30 \mathrm{~min}$. (C) hGST P1-1 $(0.05 \mathrm{mg} / \mathrm{mL})$ and 4-OHEN $(50 \mu \mathrm{M})$ were preincubated for the time intervals shown followed by addition of IAtag (50 $\mu \mathrm{M}$ ) and incubation for a further $30 \mathrm{~min}$. (D \& E) hGST P1-1 $(0.2 \mathrm{mg} / \mathrm{mL}$ ) was incubated with 
raloxifene COATag $(30 \mu \mathrm{M})$ and (D) various amounts of tyrosinase (3960 units $/ \mathrm{mg}$ ) for 30 $\mathrm{min}$; or (E) tyrosinase $(0.03 \mathrm{mg} / \mathrm{mL})$ for various times. All the reactions were performed in phosphate buffer ( $\mathrm{pH} 7.4)$ at $37^{\circ} \mathrm{C}$ and terminated by addition of $\beta$-mercaptoethanol $(0.2 \mathrm{mM})$. Proteins ( $2 \mu \mathrm{g} / \mathrm{lane})$ were loaded onto the $12 \%$ NuPAGE gel for electrophoresis at constant $200 \mathrm{~V}$ for $50 \mathrm{~min}$, and then transblotted onto PVDF membrane for western blot analysis; further experimental conditions are described in the text. 


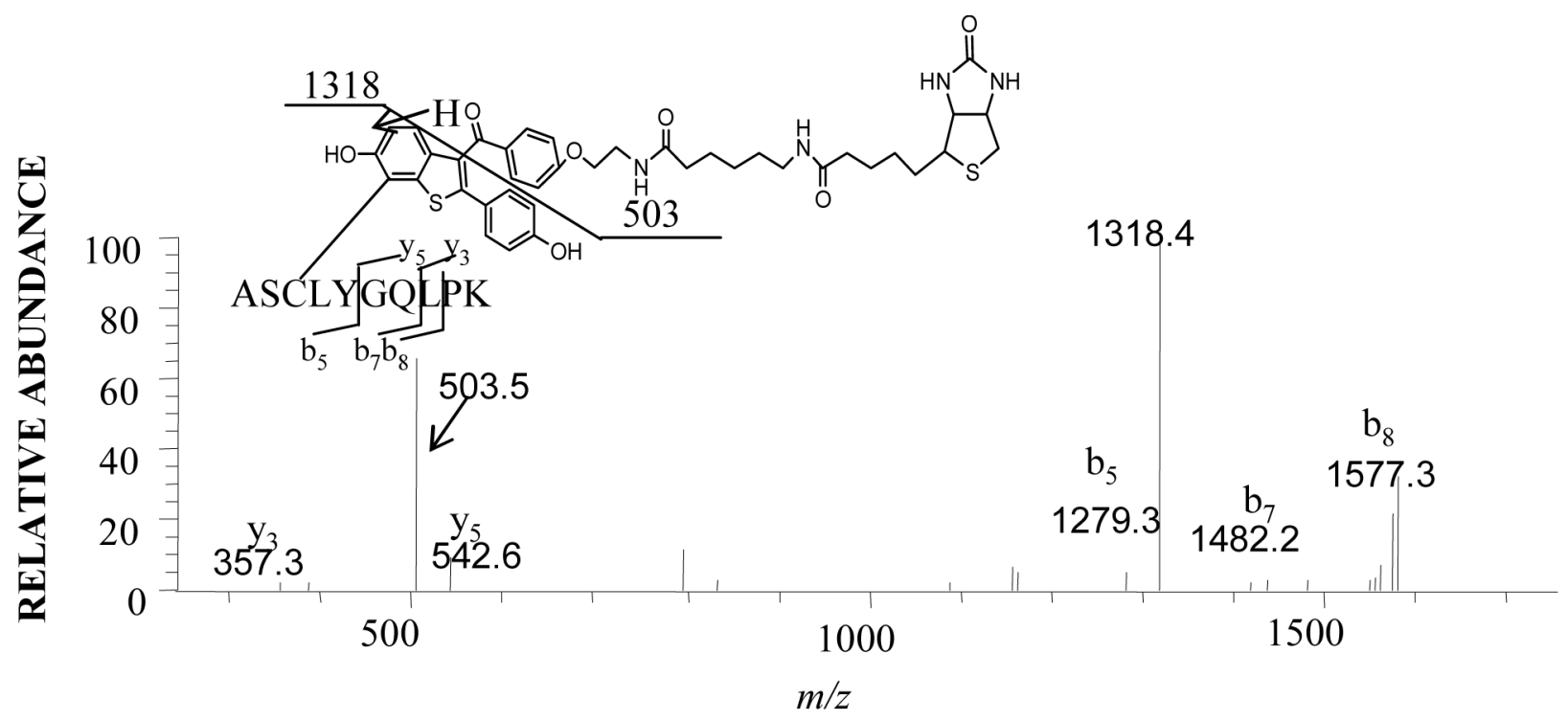

Figure 3.

Positive ion electrospray LC-MS-MS analysis of the modified peptides obtained from the tryptic digest of hGST P1-1 modified by the raloxifene COATag. After incubation of hGST P1-1 with COATag as described in the text, the protein mixture $(1 \mathrm{mg} / \mathrm{mL}$ in $200 \mu \mathrm{L}$ $\mathrm{NH}_{4} \mathrm{HCO}_{3}$ buffer, $\left.\mathrm{pH} 8.5\right)$ was digested with trypsin $(1 \mu \mathrm{g})$ overnight at $37{ }^{\circ} \mathrm{C}$. An avidin cartridge was used to concentrate only modified peptides prior to LC-MS-MS. Shown is the product ion tandem mass spectrum obtained using CID of the doubly protonated COATagged peptide, ASC(COATag)LYGQLPK ( $m / z$ 911). 

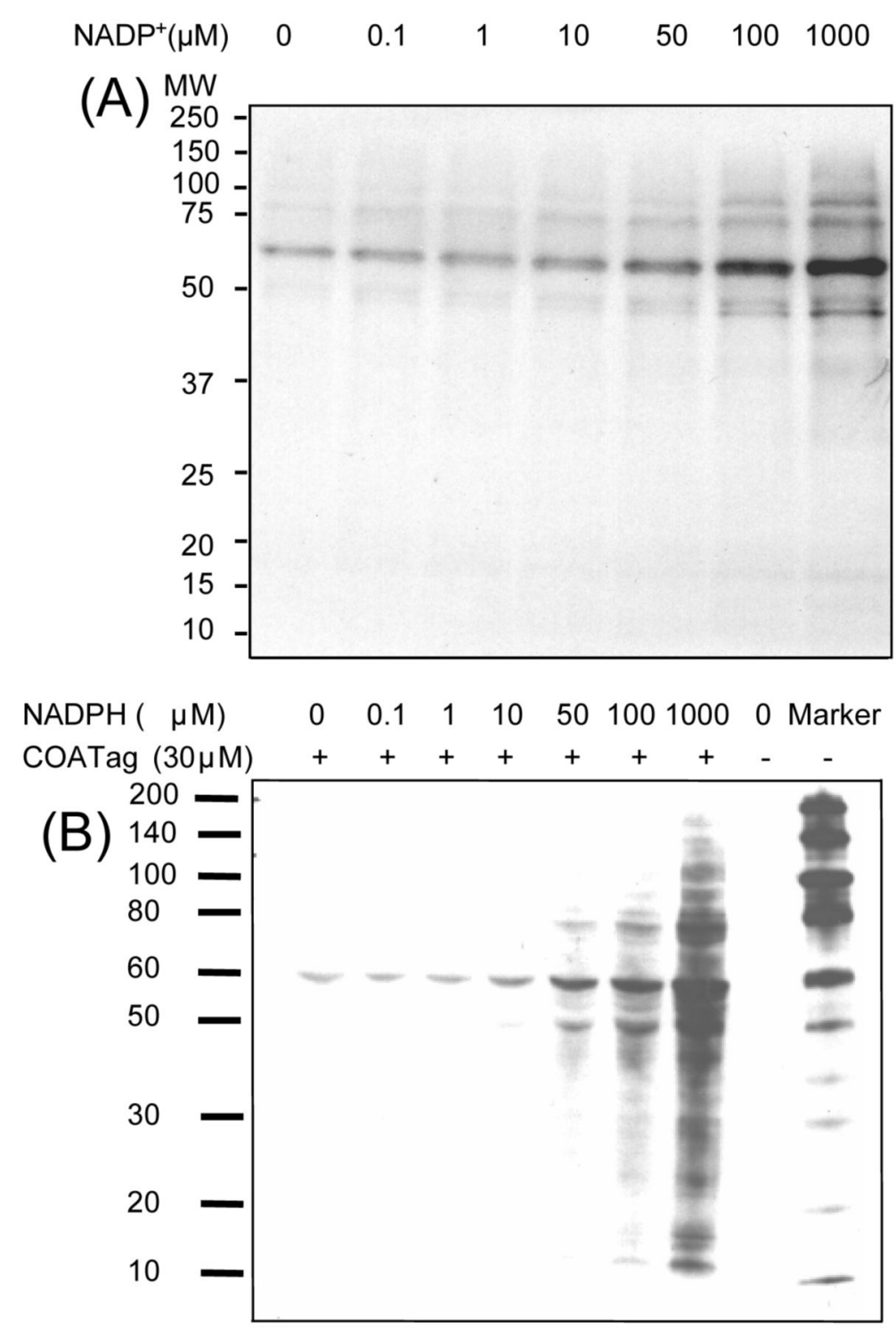

$\beta$-actin

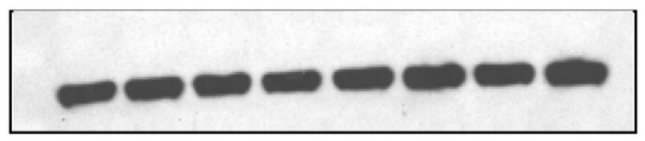

Figure 4.

Western blot analysis of rat liver microsomal proteins modified by raloxifene COATag showing NADPH-dependence. Rat liver microsomes $(1.5 \mathrm{mg} / \mathrm{mL})$ were incubated with raloxifene COATag $(30 \mu \mathrm{M})$ and (a) an NADPH generating system various concentrations of $\mathrm{NADP}^{+}$or (b) NADPH itself for $30 \mathrm{~min}$. Different rat liver microsomal preparations were used for the two experiments. The reaction mixture ( $2 \mu \mathrm{g}$ proteins/lane) was loaded onto $4-12 \%$ NuPAGE for electrophoresis at a constant $200 \mathrm{~V}$ for $50 \mathrm{~min}$ and then transblotted onto PVDF membrane for western blot analysis. The immunoblots shown are representative of triplicate analyses. 
A)

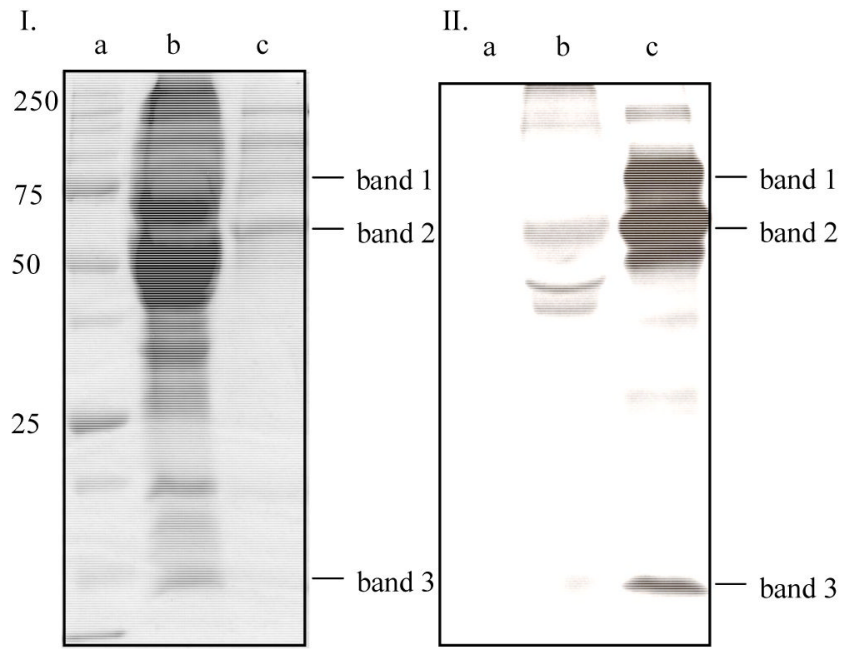

B)

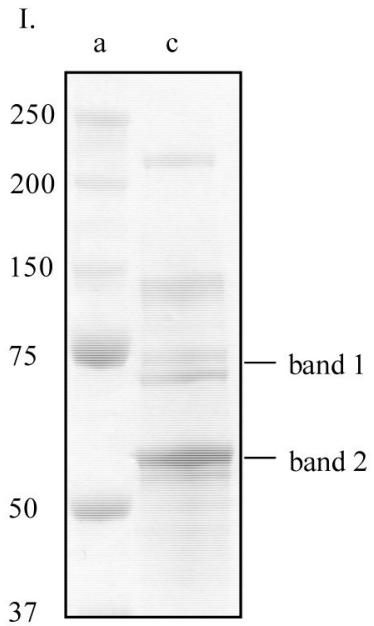

II

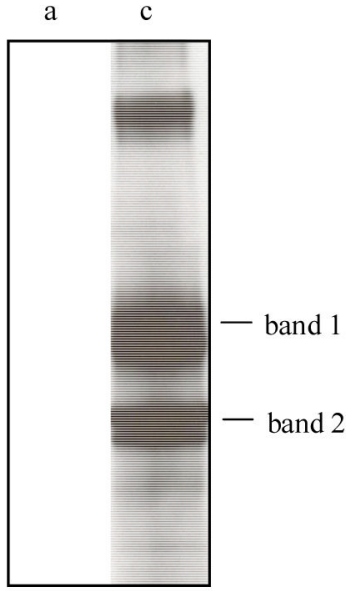

C)

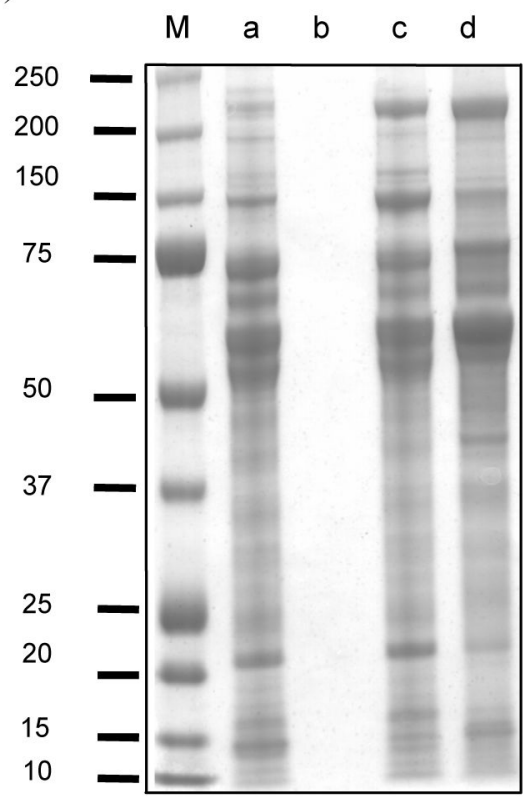

D)

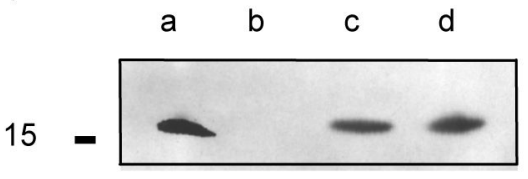

Figure 5.

Analysis of raloxifene COATagged rat liver microsomal proteins relative to total protein. After incubation of rat liver microsomes with raloxifene COATag, microsomal proteins were isolated using an avidin column, separated on 4-12\% NuPAGE gels (MOPS running buffer), run at either (A) $200 \mathrm{~V}, 1 \mathrm{~h}$. or (B) $100 \mathrm{~V}, 1.5 \mathrm{~h}+150 \mathrm{~V}, 2.5 \mathrm{~h}$. The major protein bands were cut and assayed under the second running conditions. Visualization was by (I.) comassie blue or (II.) HRP-streptavidin after transblotting onto PDVF membrane. Lanes: (a) MW Markers; (b) PBS eluate; (c) biotin eluate. (C) Control experiment with rat liver microsomal proteins using Coomassie blue staining, Lanes: (M) molecular weight markers; (a) rat liver microsomes PBS (0.1 $\mathrm{M} \mathrm{K}_{2} \mathrm{PO}_{4}, 1 \mathrm{M} \mathrm{NaCl}, 0.1 \%$ tween 20, pH 5.0) avidin wash -COATag; (b) biotin eluate from avidin column -COATag; (c) PBS avidin wash +COATag; (d) biotin eluate from avidin column +COATag.. Lanes a, c, and d are loaded with equal amounts of total protein. (D) Western blot of microsomal proteins using anti-mGST antibody; the lanes correspond to protein treatment and avidin capture as described in (C). 


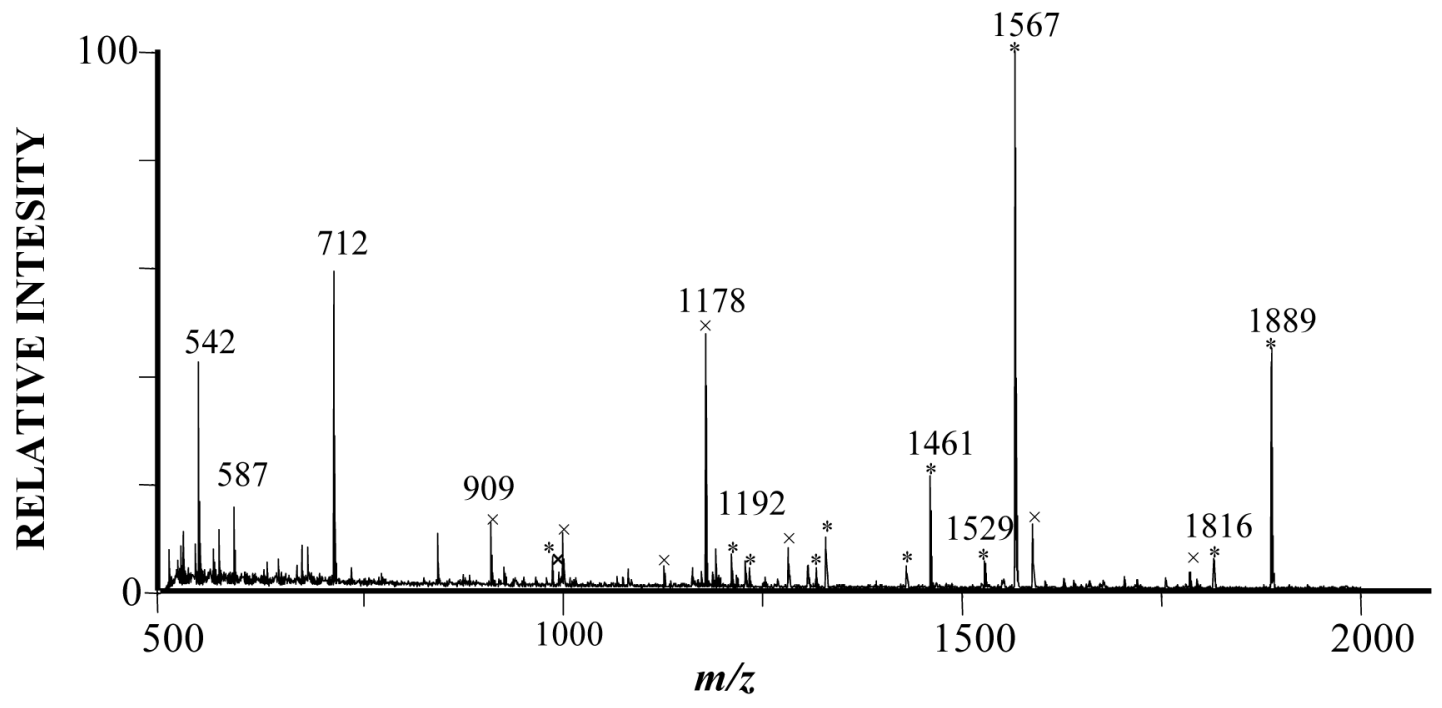

Figure 6.

Positive ion MALDI-TOF mass spectrum of tryptic digests of band 1 in fig. 5. Fragments marked $*$ are GRP 78 peptides; marked $\times$ are PIIA4 peptides. 
A<smiles>[X]c1ccc(OCCN2CCCCC2)cc1</smiles>

raloxifene: $\mathrm{X}=\mathrm{CO}, \mathrm{R}=\mathrm{H}$ arzoxifene: $\mathrm{X}=\mathrm{O}, \mathrm{R}=\mathrm{CH}_{3}$<smiles>CC/C(=C(\c1ccccc1)c1ccc(O)cc1)c1ccc(OCCN(C)C)cc1</smiles>

4-hydroxytamoxifen acolbifene<smiles>CC=C(C)OCCN1CCCCC1</smiles>
$\mathrm{HO}^{-}$ equilenin<smiles>[R]c1c(-c2ccc(O)cc2)sc2c([R])c(-c3ccc(O)cc3)ccc12</smiles>

Scheme 1.

(A) Structures of SERMs and equilenin. (B) Quinoid oxidative reactive intermediates from raloxifene. 


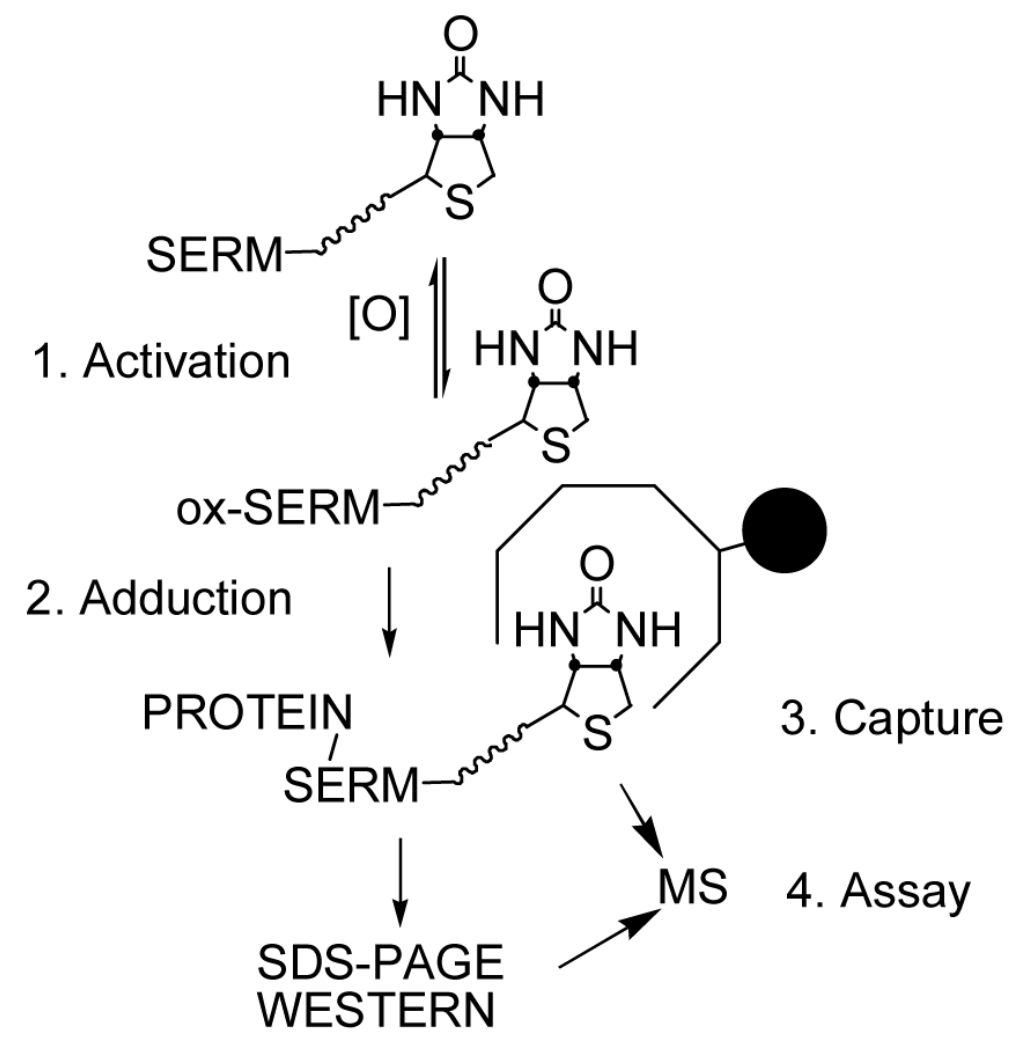

Scheme 2. 


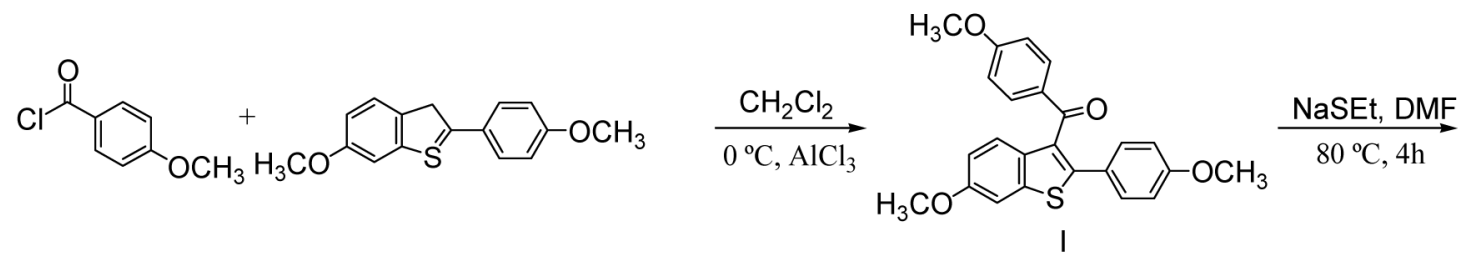<smiles>CCOC(=O)OCC(C)(C)C(=O)NCCBr</smiles><smiles></smiles>

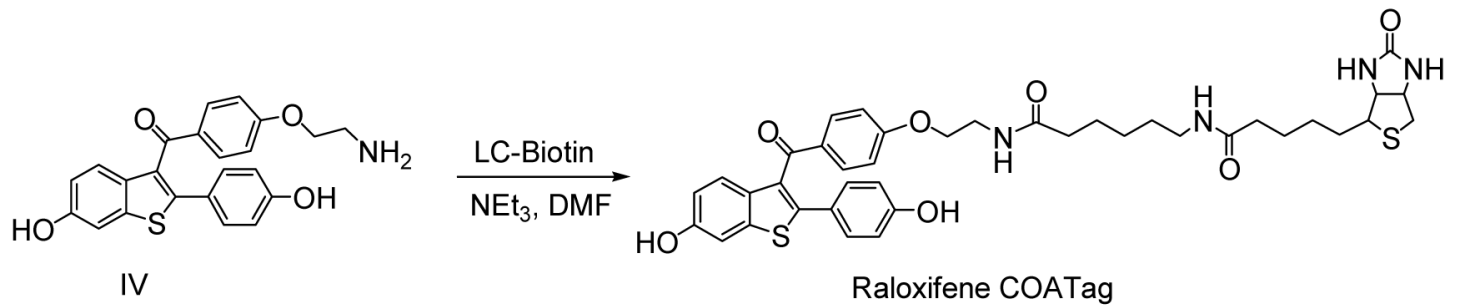

Scheme 3. 
A. Oxidative metabolism of COATag generates a quinoid electrophile thence protein covalent adduction to give COATagged protein

$$
\begin{aligned}
& \text { SERM-COATag } \stackrel{[\mathrm{O}]}{\longrightarrow} \text { ox-SERM-COATag } \stackrel{\text { protein }-\mathrm{SH}}{\longrightarrow} \text { protein - S-SERM-COATag } \\
& \text { SERM-COATag } \stackrel{\text { protein }}{\stackrel{\text { SH }}{\longrightarrow}}
\end{aligned}
$$

B. A bare electrophile tag, such as the iodoacetamide tag (IATag) reacts without need for oxidative or other bioactivation. Oxidizing environments giving protein oxidation lead to loss of reactivity with IAtag

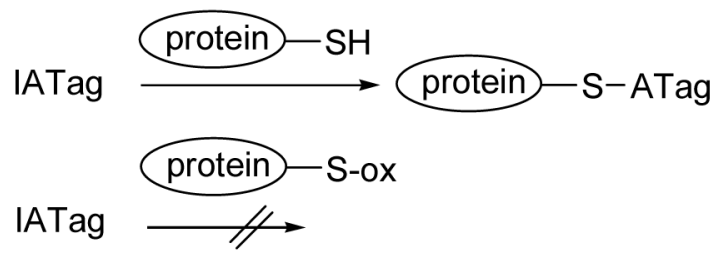

C. Oxidative metabolism of a SERM generates a quinoid oxidant that leads to protein oxidation either directly or via redox cycling; the resulting loss of free thiols by both protein oxidative and covalent modification can be quantified by the loss of reactivity with IAtag

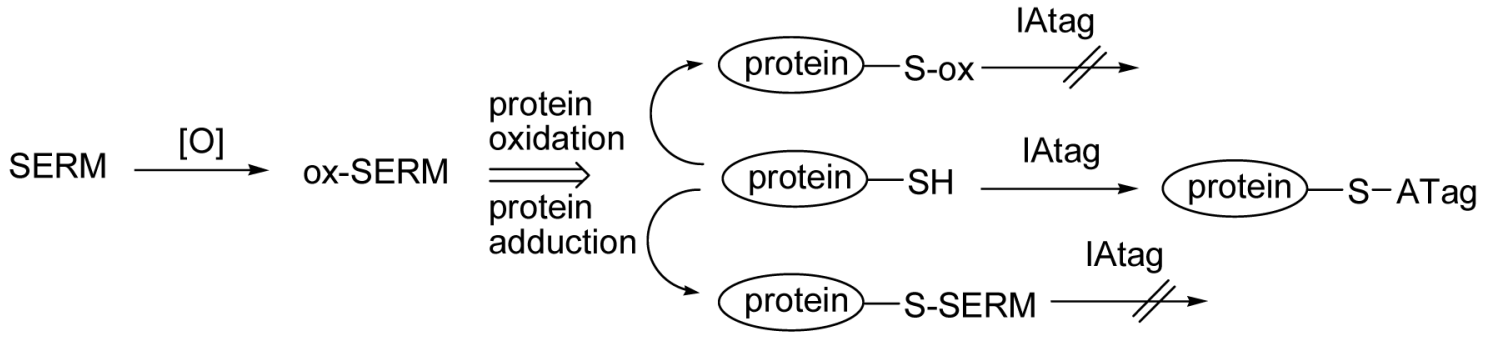

Scheme 4. 
Table 1

Proteins Identified in NuPAGE gel by mass spectrometric analysis ${ }^{a}$

\begin{tabular}{cccl}
\hline band & peptide matches & percent coverage & protein identified \\
\hline 1 & 15 & 21 & $\begin{array}{l}78 \text { kDa glucose-regulated protein, precursor; synonyms: GRP78, } \\
\text { immunoglobulin, heavy-chain binding protein, Bip, steroidogenesis- } \\
\text { activator } \\
72 \mathrm{kDa} \text {, protein disulfide isomerase A4 precursor; synonyms: protein } \\
\text { ERp-72 (ERp72), calcium-binding protein 2 (CaBP2) }\end{array}$ \\
\hline 11 & 17 & 47 & $\begin{array}{l}57 \mathrm{kDa} \text {, protein disulfide isomerase, precursor; synonyms: PDI, } \\
\text { prolyl-4-hydroxylase beta subunit, cellular thyroid hormone binding } \\
\text { protein, thyroxine deiodinase, iodothyronine 5'-monodeiodinase, 5'- } \\
\text { MD } \\
57 \text { kDa, protein disulfide isomerase, A3 precursor; synonyms: } \\
\text { Disulfide isomerase ER-60 (ERp 60), P58, HIP-70 }\end{array}$ \\
\hline
\end{tabular}

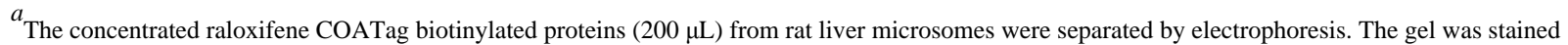
by Coomassie blue, excised, and digested with trypsin. The trypsin digests from band 1 and band 2 (see fig. 5) were identified by MALDI-TOF and ESMS-MS respectively. Percent coverage is calculated based on the sequence of the processed protein. Duplicate and full analyses are provided in Supporting Information. 